\title{
Association of Toll -like Receptors 1, 2, 4, 6,8, 9 and 10 Genes Polymorphisms and Susceptibility to Tuberculosis in Sudanese Patients
}

Najwa A Mhmoud ( $\square$ infkogodaster@gmail.com )

University of Khartoum. Khartoum

\section{Research Article}

Keywords: Tuberculosis, Toll-like receptors, and PCR-RFLP.

Posted Date: September 15th, 2021

DOl: https://doi.org/10.21203/rs.3.rs-850575/v1

License: (c) (i) This work is licensed under a Creative Commons Attribution 4.0 International License. Read Full License 


\section{Abstract}

Background: Genetic factors are important contributors to the development of a wide range of complex disease. Polymorphisms in genes encoding for toll like receptors (TLRs) usually influence the efficiency of the immune response to infection and are associated with disease susceptibility and progression. Therefore, we aims to describe the first association between TLR1, TLR2, TLR4 TLR6, TLR8, TLR9 ,and TLR10 genes polymorphisms and susceptibility to tuberculosis in Sudanese patients.

Methodology: Here we performed a case study which included 160 tuberculosis patients and 220 healthy matched controls from Sudan. In the study population, we evaluated the possible association between 86 markers in TLR1, TLR2, TLR4 TLR6, TLR8, TLR9, and TLR10 genes polymorphisms and susceptibility to tuberculosis disease in Sudanese population using polymerase chain reaction and restriction fragment length polymorphism (PCR-RFLP) .

Result: From our results It appeared that in the tuberculosis population the TLR1 rs5743557, TLR1 rs4833095, TLR1 rs5743596, TLR2 rs5743704, TLR2 rs5743708, TLR2 rs3804099, TLR4 rs4986790,TLR4 rs4986791, TLR6 rs5743810, TLR8 rs3764879, TLR8 rs3764880, TLR9 rs352165, TLR9 rs352167, TLR9 rs187084 and TLR10 rs4129009 were significantly more often encountered $(p<0.0001)$ than in the control population and were associated with tuberculosis in the Sudanese population. For the other polymorphisms tested, no association with tuberculosis was found in the population tested.

Conclusion: This indicates that the genotypes obtained for TLR1 rs5743557, TLR1 rs4833095, TLR1 rs5743596, TLR2 rs5743704, TLR2 rs5743708, TLR2 rs3804099, TLR4 rs4986790,TLR4 rs4986791, TLR6 rs5743810, TLR8 rs3764879 , TLR8 rs3764880, TLR9 rs352165, TLR9 rs352167, TLR9 rs187084 and TLR10 rs4129009 allele have a significant role in the genetic susceptibility to development tuberculosis in Sudanese population.

\section{Background}

Tuberculosis (TB) has been declared a major public health problem worldwide, due to the emergence of almost untreatable strains of Mycobacterium tuberculosis (M. tuberculosis). In addition, to that the only existing vaccine against TB, the BCG vaccine, fails to protect against pulmonary TB, the most important form of disease manifestation [1]. It kills approximately 10 million people and nine million of new TB cases are reported worldwide annually [1, 2].

In the last two decades, three major coronavirus epidemics have been reported worldwide [3]. The burden of COVID-19, and TB is one of the major and persistent global health challenges of the twenty-first century $[4,5]$.

The intersecting coronavirus and TB epidemics in countries with a high burden of TB infections pose several public health challenges. In fact, TB is the leading immune suppressing infection and the most common cause of death among HIV-infected patients [6]. WHO estimated that 1.1 million people worldwide live with TB and HIV, 80\% of whom live in sub-Saharan Africa [7, 8]. and causing a high mortality rate among people living with HIV/AIDS over the last ten years [9] Populations infected with HIV and TB, those with undiagnosed pulmonary TB (PTB), drug resistant tuberculosis or complex presentations such as disseminated types and those who have only started PTB treatment may be at elevated risk for severe responses if they are infected with COVID-19 [10]. In the future, lung lesions associated with COVID-19 may increase the risk of PTB, which induces a true fierce circle of HIVTB-COVID-19 co-infection.

Genetic factors are important contributors to the development of a wide range of complex disease [11, 12]. A person who is susceptible to a particular infectious disease, such as TB, the risk of developing the disease is higher than one who has not inherited the genetic risk factor $[11,12]$. Several lines of evidence had suggested the importance of host genetic factors in TB susceptibility including the most striking example of a population acquiring resistance to TB occurred in the population of Qu' Appelle Indians [13], twin studies [14], genome-wide linkage studies [15-19], and recently published genome-wide association studies (GWAS) [20, 21].

These evidences on the influence of host genetic factors in TB susceptibility led to the development of strategies to identify candidate genes or susceptibility loci in the human genome. Identification of polymorphisms in genes has enabled linkage and association studies to be used in explaining individual variation in susceptibility to and severity of TB in humans. 
In this context, toll like receptors (TLRs) are a family of proteins that are expressed either on the extra cellular cell surface (TLR1, $2,4,5,6)$ or in the cytosol or on endosomal membranes (TLR3, 7, 8, 9) of macrophages and dendritic cells. TLRs are essential for recognition of a broad repertoire of pathogen-associated molecular patterns (PAMPs) on macrophages and dendritic cells and play an important role in the innate responses against $M$. tuberculosis [22-26]. Genetic variations of TLR1, TLR2, TLR4, TLR6, TLR8, TLR9 and TLR10 have been associated with the susceptibility to TB in different ethnic groups [27-33]. In contrast, other studies have failed to demonstrate significant associations of TLRs polymorphisms with TB [34-37].

Hence, the identification of mutations in these receptors could be used as a marker to screen the individuals who are at risk. Therefore the aim of the present study is to determine the possible association between 86 single-nucleotide polymorphisms (SNPs) of TLR1, TLR2, TLR4 TLR6, TLR8, TLR9 , and TLR10 with pulmonary tuberculosis in a sub-Saharan Sudanese tuberculosis patients .

\section{Materials And Methods}

\section{Study population}

A prospective, cross sectional, case-control study was carried out during the period between 2019 and 2020 at Abu-Angah Hospital , Khartoum, Sudan. 160 patients with active pulmonary TB and 220 healthy controls were included. EDTA blood samples were taken from all patients and healthy controls. All tuberculosis patients had microbiological (by culture and/or smear) or radiological evidence of $M$. tuberculosis disease (table 1).

The healthy controls had no evidence of tuberculosis disease by clinical examination, and were matched on age, gender and BCG status (table 1).

The collected blood samples were tested for other infectious diseases and that included hepatitis B (HBsAg, InTec products, INC, China), hepatitis C (Rapid Anti-HCV Test, InTec products, INC, China), syphilis (RAPIDAN TESTER, product code: RTTP01, Turkey), and HIV (HIV1, 2 Cassete test, Clinotech Diagnostics \& Pharmaceuticals, Canada). Blood samples were stored at $-20^{\circ} \mathrm{C}$ until use. Nasopharyngeal swab for was used to define Corona Vlrus Disease-2019 (COVID-19)

\section{Ethics statement}

The present study was approved by the Ethics Committee of University of Khartoum, Khartoum, Sudan (5/2018). Written informed consents were obtained from all participants in the study.

\section{DNA isolation}

Genomic DNA was isolated from blood samples with the large volume kit for the MagNA Pure system (Roche, Almere, The Netherlands) according to the manufacturer's descriptions. The isolated DNA was stored at $-20^{\circ} \mathrm{C}$.

\section{Genotyping}

Genomic variants of TLR1(rs5743604, rs5743611, rs5743618, rs76600635, rs5743551, rs5743557, rs5743565, rs5743566, rs5743580, rs5743594 rs4833095, rs5743595, rs5743596); TLR2 (rs1816702, rs5743704 rs5743708, rs7656411, rs11938228, rs893629, rs1898830,rs121917864, rs4696480, rs3804099, rs5743699 rs3804100); TLR4 (rs7869402, rs1927907, rs1927911, rs1927914, rs6478317, rs55912718, rs5030719, rs10759931, rs10759933, rs2770150, rs1554973,

rs11536878, rs11536879, rs7873784, rs11536889, rs4986790, rs4986791, rs11536897, rs11536898); TLR6

(rs3796508,rs5743810, rs5743831, rs1039559, rs6531670, rs5743788, rs5743794); TLR8

(rs4830805, rs4830808, rs3747414, rs3761624, rs1548731, rs2109134, rs3788935, rs1013150, rs5744068, rs3764879, rs5744080, rs3764880, rs17256081, rs5741883, rs2407992, rs178998); TLR9 (rs5743836, rs164637, rs352139, rs352140, rs352143, rs352162, rs352165, rs352167, rs187084); and TLR10 (rs4129009, rs7694115, rs10856839, rs11466645, rs4274855, rs11096955, rs11096956, rs11096957, rs7698870, and rs10776483) genes were detected by PCR followed by restriction enzyme fragment analysis (PCR-RFLP). All PCR primers are stated in Table 2. Each of the PCRs consisted 
of a pre-denaturation step of 4 minutes at $94^{\circ} \mathrm{C}$ and 40 cycles each of 30 seconds denaturation at $94^{\circ} \mathrm{C}, 30$ seconds annealing at $55^{\circ} \mathrm{C}$ and 30 seconds elongation at $72^{\circ} \mathrm{C}$. This was followed by a post-elongation step of 7 minutes at $72^{\circ} \mathrm{C}$. Restriction endonucleases were selected using the NEBcutter software (http://nc2.neb.com/NEBcutter2/). Restriction endonucleases were obtained from Fermentas (st. Leon-rot, Germany), and Roche (Penzberg, Germany) and were used as described by the manufacturer. Restriction fragments were visualized by electrophoresis on $2 \%$ agarose gels (Hispanagar, Sphaero Q, Leiden, The Netherlands).

\section{Statistical analysis}

The mean age of the patient population and the control population were compared by the unpaired t-test. Gender, occupation and BCG-vaccination status between the patient and control population were compared with the Fisher exact test. Verification of Hardy-Weinberg equilibrium (HWE) was performed with Pearson's $\chi 2$ test. The effect of the TLR1(rs5743604, rs5743611, rs5743618, rs76600635, rs5743551, rs5743557, rs5743565, rs5743566, rs5743580, rs5743594 rs4833095, rs5743595, rs5743596); TLR2 (rs1816702, rs5743704 rs5743708, rs7656411, rs11938228, rs893629, rs1898830,rs121917864, rs4696480, rs3804099, rs5743699 rs3804100); TLR4 (rs7869402, rs1927907, rs1927911, rs1927914, rs6478317, rs55912718, rs5030719, rs10759931, rs10759933, rs2770150, rs1554973, rs11536878, rs11536879, rs7873784, rs11536889, rs4986790, rs4986791, rs11536897, rs11536898);TLR6 (rs3796508,rs5743810, rs5743831, rs1039559, rs6531670, rs5743788, rs5743794); TLR8 (rs4830805, rs4830808, rs3747414, rs3761624, rs1548731, rs2109134, rs3788935, rs1013150, rs5744068, rs3764879, rs5744080, rs3764880, rs17256081, rs5741883, rs2407992, rs178998); TLR9 (rs5743836, rs164637, rs352139, rs352140, rs352143, rs352162, rs352165, rs352167, rs187084); and TLR10 (rs4129009, rs7694115, rs10856839, rs11466645, rs4274855, rs11096955, rs11096956, rs11096957, rs7698870, and rs10776483) polymorphisms on susceptibility to tuberculosis were assessed with the Fisher exact test. P-value of $<0.05$ was deemed statistically significant All statistical analyses were performed using SPSS for Windows v11.0 statistical analysis software.

\section{Results}

\section{Characteristics of tuberculosis patients and healthy control subjects}

One hundred and sixty Sudanese tuberculosis patients were included into the study. The diagnosis of tuberculosis was based on the presence of MTB in a positive Ziehl-Nielson (ZN) smear of a sputum specimen and/or by positive culture with tuberculosis and radiological evidence (chest X-ray) (table 1).The control population comprised 220 healthy unrelated people from the same endemic area in Sudan, they were matched on gender and BCG-status (table 1) and showed no signs of any lung disease. Unfortunately the occupation of the control population differed from that of the patient population.

\section{Distribution of TLR1, TLR2, TLR4 TLR6 , TLR8 , TLR9 , and TLR10 genes polymorphisms:}

To detect the possible deficiencies in TLR1(rs5743604, rs5743611, rs5743618, rs76600635, rs5743551, rs5743557, rs5743565, rs5743566, rs5743580, rs5743594 rs4833095, rs5743595, rs5743596); TLR2 (rs1816702, rs5743704 rs5743708, rs7656411, rs11938228, rs893629, rs1898830,rs121917864, rs4696480, rs3804099, rs5743699 rs3804100); TLR4 (rs7869402, rs1927907, rs1927911, rs1927914, rs6478317, rs55912718, rs5030719, rs10759931, rs10759933, rs2770150, rs1554973, rs11536878, rs11536879, rs7873784, rs11536889, rs4986790, rs4986791, rs11536897, rs11536898); TLR6 (rs3796508,rs5743810, rs5743831, rs1039559, rs6531670, rs5743788, rs5743794) TLR8 (rs4830805, rs4830808, rs3747414, rs3761624, rs1548731, rs2109134, rs3788935, rs1013150, rs5744068, rs3764879, rs5744080, rs3764880, rs17256081, rs5741883, rs2407992, rs178998); TLR9 (rs5743836, rs164637, rs352139, rs352140, rs352143, rs352162, rs352165, rs352167, rs187084); and TLR10 (rs4129009, rs7694115, rs10856839, rs11466645, rs4274855, rs11096955, rs11096956, rs11096957, rs7698870, and rs10776483) production among tuberculosis patients, genotype (table 3 ) and allele frequencies (table 4) in the promoters of the genes encoding for TLR1, TLR2, TLR4, and TLR6 were determined. To determine if the SNPs reached Hardy-Weinberg equilibrium (HWE), the Pearson's $\chi 2$ test was performed. It appeared that in the patients and control population, all genotype distributions were in Hardy-Weinberg disequilibrium. 
To determine if there was an association between any of the studied SNPs and tuberculosis, the allele frequencies between the control population and the patient population were compared with the Fisher Exact test. It appeared that in the tuberculosis population the TLR1 rs5743557, TLR1 rs4833095, TLR1 rs5743596, TLR2 rs5743704, TLR2 rs5743708, TLR2 rs3804099, TLR4 rs4986790, TLR4 rs4986791, TLR6 rs5743810, TLR8 rs3764879, TLR8 rs3764880, TLR9 rs352165, TLR9 rs352167, TLR9 rs187084 and TLR10 rs4129009 were significantly more often encountered $(p<0.0001)$ (Table 4) than in the control population and were associated with tuberculosis in the Sudanese population (Table 4) .For the other polymorphisms tested, no association with tuberculosis was found in the population tested (Table 4).

\section{Discussion}

\section{Association between TLR1, TLR2, TLR4 TLR6, TLR8, TLR9, and TLR10 genes polymorphisms and tuberculosis:}

Tuberculosis is a complex disease in which environmental, immunological and genetic factors are contributed. It has been estimated that $10 \%$ of the infected population with $M$. tuberculosis may develop TB disease sometime in their life, suggesting that the majority of those infected are endowed with a protective immune response. Previous association studies have indicated a potential involvement of genetic variation within innate immune response genes as risk factors for TB. In particular, TLR1 [38], TLR2 [39-44] TLR4 [45], with TLR8 [46] and TLR9 [30] genetic variants have been associated with TB, suggesting that TLRmediated responses may be important for protection to M. tuberculosis infection in humans.

TLRs are a family of PRRs consisting of 12 members in human and other mammals. TLRs play a crucial role in the recognition of $M$. tuberculosis, this immune activation occurs only in the presence of functional TLRs. Variants of TLRs may influence their expression, function and alters the recognition or signaling mechanism, which leads to the disease susceptibility [47, 48]. The polymorphisms of TLRs have been hypothesized to affect the tuberculosis susceptibility. However, the direct evidence remains controversial.

Therefore, in the present study, we genotyped 86 SNPs including TLR1, TLR2, TLR4 TLR6, TLR8, TLR9, and TLR10 in the Sudanese tuberculosis patients to determine whether they are associated with susceptibility to TB in Sudanese tuberculosis patients.

Our results revealed that TLR1 rs5743557, TLR1 rs4833095, and TLR1 rs5743596 allele were more frequently found in the patients population compared to the healthy controls population. The association of the TLR1 rs5743557, TLR1 rs4833095,and TLR1 rs5743596 allele with tuberculosis were also found in other populations originating from Caucasian, Indian population and South Asian for TLR1 rs4833095 [32, 49] and, East Asian Population for TLR1 rs5743557 [32], but not in populations originating from in North China.[32] and African American subpopulation [38]. Further, in vitro experiments showed that the TLR1 rs4833095 is in strong linkage disequilibrium (LD) with TLR1 rs5743618 and determining how these two SNPs contribute to TB susceptibility has proven difficult. TLR1 rs5743618 -GT genotype was related to reduction in surface expression of TLR1 in monocytes and granulocytes. In addition, after stimulated by inactivated H37Rv, samples from children with the rs5743618-GT genotype showed a decreased production of TNF- $a$ and CXCL10, invariable production of IL-6 and IL-8 and increased production of IL-10 [50 ]. In Spanish population, rs5743618 G allele and GG genotype influenced the susceptibility to PTB [33]; in Han Chinese population, Ma et al. reported that rs5743618 was not associated with adult TB [38] .Zhang et al. [32] conducted a metaanalysis on TLR1 rs5743618 and also found no association with TB susceptibility, which corresponds with our results [32]. Salie et al. performed an association study of 23 polymorphisms in five TLR genes (TLR1, TLR2, TLR4, TLR8, and TLR9) in TB cases and healthy controls in a South African population. The study found that TLR1 rs5743618, TLR8 rs3764879, and TLR8 rs3764880 polymorphisms were associated with TB susceptibility in both sexes [51].

Our results also revealed that TLR2 rs5743708, TLR2 rs3804099 were more frequently found in the patient population compared to the healthy control population. The association of the TLR2 rs5743708, with tuberculosis were also found in other populations originating from Asian and Hispanic populations [39, 52, 53] but not European subgroup [51]. Zhang et al. [32] showed a significant association with TB susceptibility for the rs5743708 A allele and AA genotype across different ethnic groups in Asians and Europeans, but decreased risk in the Hispanic population [32]. 
In contrast, the TLR2 rs5743708 and TLR2 rs5743704 were not associated with TB meningitis in an Indian population.[36, 54] TLR2 rs3804099 was associated with susceptibility to TB meningitis rather than with susceptibility to pulmonary TB in a casecontrol study of a Chinese cohort.[55] Another study investigated possible associations of 16 polymorphisms of six TLR genes and TIRAP with TB susceptibility in a Chinese population. It found that TLR2 rs5743708, polymorphism was associated with pulmonary TB [52].

Several studies have demonstrated critical role of TLR4 in M. tuberculosis recognition and verified necessity of these TLR for development of a protective response against M. tuberculosis infection [40]. Variants in TLR4, rs4986790 and rs4986791, were investigated for their association with susceptibility or resistance to pulmonary tuberculosis [27, $28,30,34,45]$.

The results of our study are consistent with the reports of Najmi et al. in India [28] Ferwerda et al. in Tanzania [45] and Pulido et al in Spain [59] but not similar to that reported previously in other Sudanese [31] and South India [56] Asian populations [34] European Caucasians [34], North and South American [34, 38], African populations [34, 38] ,Gambian TB population [57], a southeastern Chinese population [58], Mexico [35], and USA[30].

It is known that for TLR6 rs5743810 SNP have a protective effect against TB development. The T allele was found by Shey et al. [60] to reduce NF-kB signalling which led to an altered level of IL-6 production, while Randhawa et al. [61] showed that it leads to increased IFN- $y$ production and thus protection against $M$. tuberculosis. These functional studies correlate with the results found in this meta-analysis as well as that of Zhang et al. [32] where the T allele and TT genotype was also associated with resistance to TB disease.

The TLR8 polymorphism plays a significant part in the immune response in regulating the induction of interferon (IFN) and inflammatory cytokines [46, 51]. Our results revealed that TLR8 rs3764879,and rs3764880 allele were more frequently found in the patients population compared to the healthy controls population. The association of the TLR8 rs3764879 and rs 3764880 alleles with tuberculosis were also found in other populations originating from Russian and Indonesian populations [46] Furthermore, associations have also been found in Turkish male children [63], Pakistan population [64], and South African population [51]. However, neither Kobayashi et al. [27] nor Chimusa et al. [65] showed any association between rs3764880 and TB susceptibility

Ethnic differences in TLR polymorphisms may in part reflect the ethnic diversity of host TB susceptibility. Davila et al. found that around $30 \%$ of the Indonesian male subjects carried the A allele (rs3764880) associated with risk for TB, whereas this same allele was present in $78 \%$ of Russian patients [46]. $34.3 \%$ of the Turkish male children with pulmonary TB had the A allele associated with risk for TB, which is similar to Indonesion population [63]. The rs3764880 polymorphism of TLR8 was observed more than $16 \%$ among the healthy Chinese adult population by Cheng et al. [66].

The gene of TLR9 is located on chromosome 3p21.3. The total length of TLR9 gene is approximate $5 \mathrm{~kb}$. Its coding gene has two exons, and the major coding region is in the second exon $[52,62]$. TLR9 is an intracellular pathogen recognition receptor (PRR) that recognizes non-methylated cytosine-phosphate-guanine (CpG) motifs in bacterial DNA [52, 62]. Based on NCBI SNP database, twelve SNPs have been identified for TLR9 gene. Studies have been indicated certain race population with special genotype of TLR9 polymorphism might have higher risk for TB. Our results revealed that TLR9 rs352165, rs352167 and rs187084 allele were more frequently found in the patients population compared to the healthy controls population. Sanchez et al found that TLR9 rs352165, rs352167 were not associated with TB risk in a Colombian population [37].

In previous study, a meta-analysis was performed to assess the association between seven extensively studied TLR9 polymorphisms (rs187084, rs352165, rs5743836,

rs5743842, rs352139, rs352140 and rs352167) and TB risk. The analysis revealed an association between certain TLR9 polymorphism and TB risk. The studies included Indians, Iranian and West African, Indonesians, Vietnamese, Chinese and Mexicans. The results showed that rs187084 and rs5743836 polymorphisms were not associated with TB risk, while the association between rs352139 polymorphism and TB risk may vary by race $[67,68]$. 
Bharti et al found that rs187084 locus may be associated with susceptibility to TB in Indian population [68] The SNP rs187084 and rs 5743836 SNPs located in the promoter are the most important and have been associated with various inflammatory diseases is located in the promoter of TLR9 gene [69-71]. Previous functional analyses have shown that both rs187084 and rs5743836 SNPs influence the transcription of TLR9 by regulation of promoter activity $[69,71,72]$. Some studies found that the rs187084 in TLR9 showed no association with TB in Vietnam and Iran [73, 74].

Our result revealed that rs5743836, rs164637, rs352139, rs352140, rs352143, and rs352162 allele may not be risk factors for susceptibility to pulmonary tuberculosis in Sudanese populations. On the other hands rs352139 has been strongly associated with susceptibility to TB in Indonesian [71] and Vietnamese populations [27, 72], African-Americans and in Mexican Amerindians. but not with Caucasians and African patients from Guinea-Bissau [30]. Sanders et al found that TLR9 rs5743836 and TLR9 rs352140 alleles have protective effect against meningococcal meningitis in Dutch children [75].

The rs5743836 in TLR9 showed a strong association with tuberculosis in African-Americans and Caucasians [31], while the association was not found in Vietnam [74] or Mexico population [73] and Chinese population [52]. Different variants of TLR9 rs352140 polymorphisms are described in the genome database [76] and in in the Asian population: in Japan [77].

TLR9 rs352142 polymorphism was positively associated with meningeal TB, while variant TWF2 rs352143 was associated with pulmonary TB in a Vietnamese cohort.[74] .

Recently, a number of studies indicated that TLR10 serves as a modulatory pattern-recognition receptor with mainly inhibitory properties on TLR2-derived immune responses, which are involved in the progression of TB [38, 39]. Our result revealed that TLR10 rs4129009 that was associated with TB susceptibility in Sudanese tuberculosis patients. Various studies found that Single-nucleotide polymorphisms in TLR10 were associated with susceptibility to tuberculosis in different ethnic groups. Ma et al. demonstrated that polymorphisms of TLR10 were significantly associated with TB in African and European Americans [38].

Bulat-Kardum et al. found that the rs11096957 AA genotype was associated with a predisposition to TB in the Caucasian population [78]. However, in the present study, we did not observe association between rs 11096957 and risk of TB, no association was also found in Han Chinese population [79]. This inconsistent result is likely due to the ethnic difference

In conclusion our result indicates that the genotypes obtained for TLR1 rs5743557, TLR1 rs4833095, TLR1 rs5743596, TLR2 rs5743704, TLR2 rs5743708, TLR2 rs3804099, TLR4 rs4986790,TLR4 rs4986791, TLR6 rs5743810, TLR8 rs3764879, TLR8 rs3764880, TLR9 rs352165, TLR9 rs352167, TLR9 rs187084 and TLR10 rs4129009 have a significant role in the genetic susceptibility to tuberculosis in Sudanese population. Further studies on interaction of these polymorphisms and their effect on immune response to TB might lead to better understanding on the pathogenesis of disease.

\section{Abbreviations}

Tuberculosis ,TB ; Mycobacterium tuberculosis ,M. tuberculosis; Toll like Receptors, TLRs ;PCR-RFLP ,polymerase chain reaction and restriction fragment length polymorphism; SNPs, single nucleotide polymorphism ;HWE ,Hardy-Weinberg equilibrium.

\section{Declarations}

Acknowledgements We would like to thank all health centers' staf for their kind collaboration and assistance. And also great thanks to all participants contributed to this work.

Authors' contributions: NAM was provided conceptual framework for the project, participated in data collection and analysis , participated in the molecular performance and writing the manuscript

Funding: Not applicable.

Availability of data and materials The datasets used and/or analyzed during the current study are available from the corresponding author on reasonable request. 
Ethics approval and consent to participate The present study was approved by the Ethics Committee of University of Khartoum, Khartoum, Sudan (5/2018). Written informed consents were obtained from all participants in the study

Consent to publish Not applicable.

Competing interests The authors declare that they have no competing interests.

\section{References}

1. Chun Xu , Peijun Tang, Cheng Ding , Chang Li , Jun Chen, Zhenlei Xu , et al. Vitamin D receptor geneFOKI polymorphism contributes to increasing the risk of HIV-negative tuberculosis: Evidence from a meta-analysis.PLoS One 2015; 10: e0140634.

2. World Health Organization. Global Tuberculosis Report 2020. Geneva, Switzerland: 2020.

3. World Health Organization. Coronavirus disease 2019 (COVID-19) Situation Report - 1972020. https://www.who.int/docs/default-source/coronaviruse/ situation-reports/20200804-covid-19-sitrep-197.pdf? sfvrsn=94f7a01d_2. Accessed 05 Aug 2020.

4. Faqihi F, Alharthy A, Noor AlFateh BA, Balahmar A, Karakitsos D. COVID-19 in a patient with active tuberculosis: A rare casereport. Respir Med Case Rep. 2020;31:101146.

5. Liu Y, Bi L, Chen Y, Wang Y, Fleming J, Yu Y. Active or latent tuberculosis increases susceptibility to COVID-19 and disease severity. MedRxiv BioRxiv 2020; doi: https://doi.org/https://doi.org/10.1101/2020.03.10.20033795.

6. Swaminathan S, Nagendran G. HIV and tuberculosis in India. J Biosci. 2008; 33(4):527-37.

7. World Health Organization. TB/HIV FACTS 2009. 2009.

https://www.who.int/tb/challenges/hiv/factsheet_hivtb_2009update.pdf. Accessed 07 May 2020.

8. Dirlikov E, Raviglione M, Scano F. Global tuberculosis control: toward the 2015 targets and beyond. Ann Intern Med. 2015;163(1):52-8.

9. Diedrich CR, Flynn JL. HIV-1/ mycobacterium tuberculosis co-infection immunology: how does HIV-1 exacerbate tuberculosis? Infect Immun. 2011; 79(4):1407-17.

10. Jiang H, Zhou Y, Tang W. Maintaining HIV care during the COVID-19 pandemic. Thelacent.2020;3018(20):30105.

11. Fernando SL, Britton WJ. Genetic susceptibility to mycobacterial disease in humans. Immunol Cell Biol. 2006; 84(2):125-37.

12. Karlsson EK, Kwiatkowski DP, Sabeti PC. Natural selection and infectious disease in human populations. Nat Rev Genet. 2014; 15(6):379-93.

13. Motulsky, AG. Metabolic polymorphisms and the role of infectious diseases in human evolution. Hum Biol 1960;32: 28-62.

14. Comstock GW. Tuberculosis in twins: a re-analysis of the Prophit survey. Rev. Respir. Dis. 1978; 117:621- 624.

15. Richard Bellamy, NuldaBeyers, Keith P. W. J. McAdam , Cyril Ruwende, Robert Gie, Priscilla Samaai, et al.. Genetic susceptibility to tuberculosis in Africans: a genome-wide scan. Natl. Acad. Sci. U. S. A. 2000; 97:8005-8009.

16. Graham S. Cooke, Sarah J. Campbell , Steve Bennett, Christian Lienhardt, Keith P. W. J. Mc Adam ,Giorgio Sirugo, et al. Mapping of a novel susceptibility locus suggests a role for MC3R and CTSZ in human tuberculosis. J. Respir. Crit. Care Med.2008; 178:203-207.

17. Moller M, Hoal EG. Current findings, challenges and novel approaches in human genetic susceptibility to tuberculosis. Tuberculosis (Edinb.) . $2010 ; 90: 71-83$. 
18. Mahasirimongkol S, Yanai H, Nishida N, Ridruechai C, Matsushita I , Ohashi J, et al. Genome-wide SNP-based linkage analysis of tuberculosis in Thais. Genes Immun.2009; 10:77- 83.

19. Miller EN, Jamieson SE, Joberty C, Fakiola M, Hudson D, Peacock CS, Cordell HJ,et al.. Genome-wide scans for leprosy and tuberculosis susceptibility genes in Brazilians. Genes Immun.2004; 5:63- 67.

20. Mahasirimongkol S, Yanai H, Mushiroda T, Promphittayarat W, Wattanapokayakit S, Phromjai J, et al.. Genome-wide association studies of tuberculosis in Asians identify distinct at-risk locus for young tuberculosis. Hum. Genet. 2012 ;57:363-367.

21. Thorsten Thye,Fredrik O. Vannberg, Sunny H. Wong, Ellis Owusu-Dabo, Ivy Osei, John Gyapong, et al. . Genome-wide association analyses identifies a susceptibility locus for tuberculosis on chromosome 18q11.2. Genet. 2010; 42:739 -741.

22. Bafica A, Scanga CA, Feng CG, Leifer C, Cheever A, Sher A: TLR9 Regulates Th1 responses and cooperates with TLR2 in mediating optimal resistance to Mycobacterium tuberculosis. J Exp Med 2005, 202:1715-1724.

23. Carvalho NB, Oliveira FS, Duraes FV, de Almeida LA, Florido M, Prata LO, Caliari MV, Appelberg R, Oliveira SC: Toll-like receptor 9 is required for full host resistance to Mycobacterium avium infection but plays no role in induction of Th1 responses. Infect Immun 2011, 79:1638-1646.

24. Chen YC, Hsiao CC, Chen CJ, Chin CH, Liu SF, Wu CC, Eng HL, Chao TY, Tsen CC, Wang YH, Lin MC: Toll-like receptor 2 gene polymorphisms, pulmonary tuberculosis, and natural killer cell counts. BMC Med Genet 2010, 11: 17.

25. Chow JC, Young DW, Golenbock DT, Christ WJ, Gusovsky F: Toll-like receptor-4 mediates lipopolysaccharide-induced signal transduction. J Biol Chem 1999, 274:10689-10692.

26. Azad AK, Sadee W, Schlesinger LS: Innate immune gene polymorphisms in tuberculosis. Infect Immun 2012, 80:3343-3359.

27. Kobayashi K, Yuliwulandari R, Yanai H, Naka I, Lien LT, Hang NT, Hijikata M, Keicho N, Tokunaga K: Association of TLR polymorphisms with development of tuberculosis in Indonesian females. Tissue Antigens 2012, 79:190-197.

28. Najmi N, Kaur G, Sharma SK, Mehra NK: Human toll-like receptor 4 polymorphisms TLR4 Asp299Gly and Thr399lle influence susceptibility and severity of pulmonary tuberculosis in the Asian Indian population. Tissue Antigens 2010, 76:102-109.

29. Thada S, Valluri V, Gaddam SL: Influence of toll like receptor gene polymorphisms to tuberculosis susceptibility in humans. Scand J Immunol 2013, 78:221-229.

30. Velez DR, Wejse C, Stryjewski ME, Abbate E, Hulme WF, Myers JL, Estevan R, Patillo SG, Olesen R, Tacconelli A, et al: Variants in toll-like receptors 2 and 9 influence susceptibility to pulmonary tuberculosis in Caucasians, African-Americans, and west Africans. Hum Genet 2010, 127:65-73.

31. Zaki HY, Leung KH, Yiu WC, Gasmelseed N, Elwali NE, Yip SP: Common polymorphisms in TLR4 gene associated with susceptibility to pulmonary tuberculosis in the Sudanese. Int J Tuberc Lung Dis 2012, 16:934-940.

32. Zhang Y, Jiang T, Yang X, Xue Y, Wang C, Liu J, Zhang X, Chen Z, Zhao M, Li JC: Toll-like receptor -1, -2, and -6 polymorphisms and pulmonary tuberculosis susceptibility: a systematic review and meta-analysis. PLoS One 2013, 8:e63357.

33. Ocejo-Vinyals JG, Puente de Mateo E, Ausin F, Aguero R, Arroyo JL, Gutierrez-Cuadra M, Farinas MC: Human toll-like receptor 1 T1805G polymorphism and susceptibility to pulmonary tuberculosis in northern Spain. Int J Tuberc Lung Dis 2013, $17: 652-654$.

34. Tian T, Jin S, Dong J, Li G: Lack of association between toll-like receptor 4 gene Asp299Gly and Thr399lle polymorphisms and tuberculosis susceptibility: a meta-analysis. Infect Genet Evol 2013, 14:156-160. 
35. Rosas-Taraco AG, Revol A, Salinas-Carmona MC, Rendon A, Caballero-Olin G, Arce-Mendoza AY: CD14 C(-159)T polymorphism is a risk factor for development of pulmonary tuberculosis. J Infect Dis 2007, 196:1698-1706.

36. Biswas D, Gupta SK, Sindhwani G, Patras A: TLR2 Polymorphisms, Arg753Gln and Arg677Trp, are not associated with increased burden of tuberculosis in Indian patients. BMC Res Notes 2009, 2:162.

37. Sanchez D, Lefebvre C, Rioux J, Garcia LF, Barrera LF: Evaluation of toll-like receptor and adaptor molecule polymorphisms for susceptibility to tuberculosis in a Colombian population. Int J Immunogenet 2012, 39:216-223.

38. Ma X, Liu Y, Gowen BB, Graviss EA, Clark AG, Musser JM. Full-exon resequencing reveals toll-like receptor variants contribute to human susceptibility to tuberculosis disease. PLoS One 2007;2:e1318.

39. Ogus, A.C., Yoldas, B., Ozdemir, T., Uguz, A., Olcen, S., Keser, I. et al. The Arg753GLn polymorphism of the human toll-like receptor 2 gene in tuberculosis disease. European Respiratory Journal 2004; 23: 219.

40. Abel, B.N. Thieblemont, V. J. F. Quesniaux et al., "Toll-like receptor 4 expression is required to control chronic Mycobacterium tuberculosis infection in mice," Journal of Immunology $2002 ; 169$ (6):3155-3162.

41. Dalgic, N., Tekin, D., Kayaalti, Z., Soylemezoglu, T., Cakir, E., Kilic, B. et al. Arg753Gln polymorphism of the human Toll-like receptor 2 gene from infection to disease in pediatric tuberculosis. Human Immunology 2011; 72: 440.

42. Ben-Ali, M., Barbouche, M.R., Bousnina, S., Chabbou, A. \& Dellagi, K. Toll-like receptor 2 Arg677Trp polymorphism is associated with susceptibility to tuberculosis in Tunisian patients. Clinical and Diagnostic Laboratory Immunology 2004;11: 625.

43. Thuong, N.T., Hawn, T.R., Thwaites, G.E., Chau, T.T., Lan, N.T., Quy, H.T. et al. A polymorphism in human TLR2 is associated with increased susceptibility to tuberculous meningitis. Genes and Immunity 2007;8: 422.

44. Etokebe, G.E., Skjeldal, F., Nilsen, N., Rodionov, D., Knezevic, J., Bulat-Kardum, L. et al. Toll-like receptor 2 (P631H) mutant impairs membrane internalization and is a dominant negative allele. Scandinavian Journal of Immunology 2010;71: 369.

45. Ferwerda, B., Kibiki, G.S., Netea, M.G., Dolmans, W.M. \& van der Ven, A.J. The toll-like receptor 4 Asp299Gly variant and tuberculosis susceptibility in HIV-infected patients in Tanzania. AIDS $2007 ; 21: 1375$.

46. Davila, S., Hibberd, M.L., Hari Dass, R., Wong, H.E., Sahiratmadja, E., Bonnard, C. et al. Genetic association and expression studies indicate a role of toll-like receptor 8 in pulmonary tuberculosis. PLoS Genetics 2008; 4: e1000218.

47. Quesniaux, V., Fremond, C., Jacobs, M., Parida, S., Nicolle, D., Yeremeev, V. et al. Toll-like receptor pathways in the immune responses to mycobacteria. Microbes and Infection 2004;6,:946.

48. Jo, E.K., Yang, C.S., Choi, C.H. , Harding, C.V. Intracellular signalling cascades regulating innate immune responses to Mycobacteria: branching out from Toll-like receptors. Cellular Microbiology 2007; 9: 1087.

49. Sinha E, Biswas SK, Mittal M, Bajaj B, Singh V, Arela N, et al. Toll-like Receptor 1743 A>G, 1805 T>G \& Toll-like Receptor 6 $745 \mathrm{C}>\mathrm{T}$ gene polymorphism and tuberculosis: a case control study of north Indian population from Agra (India). Hum Immunol. 2014; 75: 880-886. PMID: 24984237

50. Dittrich N, Berrocal-Almanza LC, Thada S, Goyal S, Slevogt H, Sumanlatha G, et al. Toll-like receptor 1 variations influence susceptibility and immune response to Mycobacterium tuberculosis. Tuberculosis (Edinb) 2015;95:328-35.

51. Salie M, Daya M, Lucas LA, Warren RM, van der Spuy GD, van Helden PD, et al. Association of Toll-like receptors with susceptibility to tuberculosis suggests sex-specific effects of TLR8 polymorphisms. Infect Genet Evol 2015;34:221-9.

52. Wu L, Hu Y, Li D, Jiang W, Xu B. Screening toll-like receptor markers to predict latent tuberculosis infection and subsequent tuberculosis disease in a Chinese population. BMC Med Genet. 2015; 16: 19. doi: 1186/s12881-015-0166-1 PMID:

Page 10/37 
25928077.

53. Folwaczny M, Glas J, Torok HP, Limbersky O, Folwaczny C. Toll-like receptor (TLR) 2 and 4 mutations in periodontal disease. Clin Exp Immunol. 2004;135(2):330-5.

54. Rizvi I, Garg RK, Jain A, Malhotra HS, Singh AK, Prakash S, et al. Vitamin D status, Vitamin D receptor and Toll like receptor-2 polymorphisms in tuberculous meningitis: A case-control study. Infection 2016;44:633-40.

55. Zhao Y, Bu H, Hong K, Yin H, Zou YL, Geng SJ, et al. Genetic polymorphisms of CCL1 rs2072069 G/A and TLR2 rs3804099 T/C in pulmonary or meningeal tuberculosis patients. Int J Clin Exp Pathol 2015;8:12608-20.

56. Selvaraj, P., Harishankar, M., Singh, B., Jawahar, M.S. , Banurekha, V.V. Toll-like receptor and TIRAP gene polymorphisms in pulmonary tuberculosis patients of South India. Tuberculosis 2010; 90:306.

57. Newport, M.J., Allen, A., Awomoyi, A.A., Dunstan, S.J., McKinney, E., Marchant, A. et al. The toll-like receptor 4 Asp299Gly variant: no influence on LPS responsiveness or susceptibility to pulmonary tuberculosis in The Gambia. Tuberculosis 2004;84: 347.

58. Xue, Y., Zhao, Z.Q., Wang, H.J., Jin, L., Liu, C.P., Wang, Y. et al. Toll-like receptors 2 and 4 gene polymorphisms in a southeastern Chinese population with tuberculosis. International Journal of Immunogenetics 2010 ; 37: 135.

59. Pulido I, Leal M, Genebat M,. Pacheco Y. M, 'aez M. E. S, Soriano-Sarabia N.The TLR4 ASP299GLY polymorphism is a risk factor for active tuberculosis in caucasian HIV-infected patients," Current HIV Research 2010 ; 8(3) : 253-258.

60. Shey MS, Randhawa AK, Bowmaker M, Smith E, Scriba TJ, de Kock M, et al. Single nucleotide polymorphisms in toll-like receptor 6 are associated with altered lipopeptide- and mycobacteria-induced interleukin- 6 secretion. Genes Immun. 2010; 11: 561-572. doi: 1038/gene.2010.14 PMID:20445564.

61. Randhawa AK, Shey MS, Keyser A, Peixoto B, Wells RD, de Kock M, et al. Association of Human TLR1 and TLR6 Deficiency with Altered Immune Responses to BCG Vaccination in South African Infants. PLoS Pathog. 2011; 7. doi:

1371/journal.ppat.1002174

62. Nilsson D, Andiappan AK, Hallden C, De Yun W, Sall T, Tim CF, et al. Toll-like receptor gene polymorphisms are associated with allergic rhinitis: a case control study. BMC Med Genet. 2012;13:66.

63. Dalgic N, Tekin D, Kayaalti Z, Cakir E, Soylemezoglu T, Sancar M. Relationship between toll-like receptor 8 gene polymorphisms and pediatric pulmonary tuberculosis. Dis Markers. 2011;31(1):33-8.

64. Bukhari M, Aslam MA, Khan A, Iram Q, Akbar A, Naz AG, et al. TLR8 gene polymorphism and association in bacterial load in southern Punjab of Pakistan: an association study with pulmonary tuberculosis. Int J Immunogenet. 2015;42(1):46-51.

65. Chimusa ER, Zaitlen N, Daya M, Moller M, van Helden PD, Mulder NJ, et al. Genome-wide association study of ancestryspecific TB risk in the south African Coloured population. Hum Mol Genet. 2014;23(3):796-809.

66. Cheng P.L., Eng H.L., Chou M.H., You H.L, Lin T.M. Genetic polymorphisms of viral infection-associated Toll-like receptors in Chinese population, Translational Research 2007;150:311-318.

67. Chen Z, Wang W, Liang J, Wang J, Feng S, Zhang G . Association between toll-like receptors 9 (TLR9) gene polymorphism and risk of pulmonary tuberculosis: meta-analysis. BMC Pulm. Med. 2015;15(1):1.

68. Bharti D, Kumar A, Mahla RS, Kumar S, Ingle H, Shankar H, Joshi B, Raut AA, Kumar H. The role of TLR9 polymorphism in susceptibility to pulmonary tuberculosis. Immunogenetics 2014; 66(12):675- 681

69. Hamann L, Glaeser C, Hamprecht A, Gross M, Gomma A, Schumann RR. Toll like receptor (TLR)-9 promotor polymorphisms and at herosclerosis. Clin Chim Acta. 2006;364(1-2):303-7.

Page $11 / 37$ 
70. Roszak A, Lianeri M, Sowinska A, Jagodzinski PP. Involvement of Toll-like Receptor 9 polymorphism in cervical cancer development. Mol Biol Rep. 2012;39(8):8425-30.

71. Ng MT, Van't Hof R, Crockett JC, Hope ME, Berry S, Thomson J, et al. Increase in NF-kappaB binding affinity of the variant C allele of the toll-like receptor 9-1237 T/C polymorphism is associated with Helicobacter pylori-induced gastric disease. Infect Immun. 2010;78(3):1345-52.

72. Fischer J, Weber ANR, Bohm S, Dickhofer S, El Maadidi S, Deichsel D, et al. Sex-specific effects of TLR9 promoter variants on spontaneous clearance of HCV infection. 2017;66(10):1829-37.

73. Torres-García D, Cruz-Lagunas A, García-Sancho Figueroa MC, Fernández-Plata R, Baez-Saldaña R, Mendoza-Milla C, Barquera R, Carrera-Eusebio A, Ramírez-Bravo S, Campos L, Angeles J . Variants in toll-like receptor 9 gene influence susceptibility to tuberculosis in a Mexican population. Transl. Med. 2013; 11:220.

74. Graustein AD, Horne DJ, Arentz M, Bang ND, Chau TT, Thwaites GE, Caws M, Thuong NT, Dunstan SJ, Hawn TR.TLR9 gene region polymorphisms and susceptibility to tuberculosis in Vietnam. Tuberculosis (Edinb). 2015; 95:190-196.

75. Sanders MS, van Well GT, Ouburg S, Lundberg PS, van Furth AM, Morré SA. Single nucleotide polymorphisms in TLR9 are highly associated with susceptibility to bacterial meningitis in children. Clin Infect Dis 2011b;52:475-80.

76. 1000 Genomes Project. http://www.ensembl.org. Akira S, Uematsu S, Takeuchi O. Pathogen recognition and innate immunity. Cell 2006;124:783-801.

77. Wujcicka W, Gaj Z, Wilczy_nski J, Nowakowska D. Possible role of TLR4 and TLR9 SNPs in protection against congenital toxoplasmosis. Eur J Clin Microbiol Infect Dis 2015;4:2121-9.

78. Bulat-Kardum LJ, Etokebe GE, Lederer P, Balen S, Dembic Z. Genetic polymorphisms in the toll-like receptor 10, interleukin (IL)17A and IL17F genes differently affect the risk for tuberculosis in Croatian population. Scand J Immunol 2015; 82(1):63-9. doi:10.1111/sji.12300

79. Tang, F., Li, Z., Wang, Y., Zhang, L., Ma, J., Zhou, T., Pan, K. . Toll-like receptor 1 and 10 polymorphisms, Helicobacter pylori susceptibility and risk of gastric lesions in a high-risk Chinese population. Infection, Genetics and Evolution 2015; 31: 263269. doi:10.1016/j.meegid.2015.02.005.

\section{Tables}

Table-1: Characteristics of the Study population 


\begin{tabular}{|c|c|c|c|c|}
\hline & & Patients & Controls & p-value \\
\hline Total number & & 160 & 220 & \\
\hline Mean age /yrs (range) & & $\begin{array}{l}26(11- \\
70)\end{array}$ & $\begin{array}{l}30(11- \\
70)\end{array}$ & 1.0 \\
\hline Gender (male/female) & & $111 / 49$ & $65 / 155$ & 0.0041 \\
\hline \multirow[t]{6}{*}{ Occupation } & Governmental employee & $22(13.8)$ & $\stackrel{21}{(9.55 \%)}$ & 0.05 \\
\hline & Workers & $\begin{array}{c}63 \\
(39.4 \%)\end{array}$ & $\begin{array}{c}44 \\
(20 \%)\end{array}$ & $<0.0001$ \\
\hline & Other job & $40(25 \%)$ & $\begin{array}{l}40 \\
(18.3 \%)\end{array}$ & 0.58 \\
\hline & Jobless & $3(1.8 \%)$ & $\begin{array}{c}13 \\
(5.9 \%)\end{array}$ & $<0.0001$ \\
\hline & Housewife & $13(8.1 \%)$ & $\begin{array}{l}17 \\
(7.7 \%)\end{array}$ & 0.03 \\
\hline & Student & $\begin{array}{c}19 \\
(11.9 \%)\end{array}$ & $\begin{array}{l}85 \\
(38.6 \%)\end{array}$ & 0.15 \\
\hline BCG vaccination & & $\begin{array}{c}112 \\
(70.6 \%)\end{array}$ & $\begin{array}{l}212 \\
(96.8 \%)\end{array}$ & 0.63 \\
\hline \multirow[t]{3}{*}{ Definite tuberculosis } & $\begin{array}{l}\text { Presence of MTB in sputum based on both smear } \\
\text { and culture }\end{array}$ & $92(57.5 \%)$ & $0(0 \%)$ & \\
\hline & $\begin{array}{l}\text { Presence of MTB in sputum specimen only by } \\
\text { smear }\end{array}$ & $109(68.1 \%)$ & $0(0 \%)$ & \\
\hline & $\begin{array}{l}\text { Presence of MTB in sputum specimen only by } \\
\text { culture }\end{array}$ & $\begin{array}{c}47 \\
(29.4 \%)\end{array}$ & $0(0 \%)$ & \\
\hline Hepatitis C test & & Negative & Negative & \\
\hline Hepatitis B Ag test & & Negative & Negative & \\
\hline HIV1, 2 test & & Negative & Negative & \\
\hline $\begin{array}{l}\text { Nasopharyngeal swab for } \\
\text { (COVID-19) }\end{array}$ & & Negative & Negative & \\
\hline
\end{tabular}

unpaired t-test

Fisher exact test

Table 2: PCR primers and restriction enzymes for genotyping the different Single Nucleotide Polymorphisms 


\begin{tabular}{|c|c|c|c|c|c|}
\hline Gene(s) & Rs number & $\begin{array}{l}\text { Primer sequence(s) } \\
\left(5^{\prime} \rightarrow-3^{\prime}\right)\end{array}$ & $\begin{array}{l}\text { Chromosome } \\
\text { position }\end{array}$ & $\begin{array}{l}\text { Gene } \\
\text { location }\end{array}$ & Reference \\
\hline \multicolumn{6}{|l|}{ TLR 1} \\
\hline \multirow[t]{3}{*}{$\mathrm{T} / \mathrm{C}$} & rs5743604 & F: GAAGAGCAGTCCCAATACCACCAT & chr4:38801285 & & {$[52,53,56,62]$} \\
\hline & & & & Intron 3 & \\
\hline & & R: GGCCCCAAGCTTCCCAAAATTA & & & \\
\hline \multirow[t]{3}{*}{$C / G$} & rs5743611 & F: GCATCTTCCATTTTGCCATTATCTTC & chr4:38798593 & & {$[52,53,56,62]$} \\
\hline & & & & exon 4 & \\
\hline & & R: CCAATTCCTGGTTGAATTTGAAAACA & & & \\
\hline \multirow[t]{3}{*}{$\mathrm{G} / \mathrm{T}$} & rs5743618 & F: TCCTCATGACTCTTTTCTGC & chr4:38797027 & & {$[52,53,56,62]$} \\
\hline & & & & Promoter & \\
\hline & & R: GAGGCTTGTCCCTTGCTCCAC & & & \\
\hline \multirow[t]{3}{*}{$A / G$} & rs76600635 & F: GCATCTTCCATTTTGCCATTATCTTC & chr4: 38800323 & & {$[52,53,56,62]$} \\
\hline & & & & intron & \\
\hline & & R: CCAATTCCTGGTTGAATTTGAAAACA & & & \\
\hline \multirow[t]{2}{*}{$A / G$} & rs5743551 & F: CCGAGATGTTCCCAGCACAG & chr4: 38806033 & Promoter & {$[52,53,56,62]$} \\
\hline & & R :CTGCTTTGCTTGTGCCTCTT & & & \\
\hline \multirow[t]{2}{*}{$\mathrm{C} / \mathrm{T}$} & rs5743557 & F:ACGTTGGATGGAGTGTGCTTCAGCAAAAC & chr4:38806827 & $\begin{array}{l}\text { near- } \\
\text { gene-5 }\end{array}$ & {$[52,53,56,62]$} \\
\hline & & R:ACGTTGGATGTCTTGCCTTTTCATCCATCC & & & \\
\hline \multirow[t]{2}{*}{$A / G$} & rs5743565 & F: ACGTTGGATGAGCTGAACAGCAGCATTGCC & chr4:38805983 & exon 2 & {$[52,53,56,62]$} \\
\hline & & R: ACGTTGGATGTTCTCTTCACCTAATCCCGC & & & \\
\hline \multirow[t]{2}{*}{$C / G$} & rs5743566 & F: ACGTTGGATGAAGGACTAGCTAGTGGGAAG & chr4:38805942 & exon 2 & {$[52,53,56,62]$} \\
\hline & & R: ACGTTGGATGAGTTACTCCCGGAGGCAATG & & & \\
\hline \multirow[t]{2}{*}{$A / G$} & rs5743580 & F:ACGTTGGATGAACATCCAGAGTGACTCAGC & chr4:38804405 & intron & {$[52,53,56,62]$} \\
\hline & & R:ACGTTGGATGTGGCTATGGTAAGCTTCTC & & & \\
\hline \multirow[t]{2}{*}{$\mathrm{C} / \mathrm{T}$} & rs5743594 & F:ACGTTGGATGGCTACTCACACAAGGAGCAA & chr4:38802751 & intron & {$[52,53,56,62]$} \\
\hline & & R:ACGTTGGATGGGGTTAGGATTTCAACATAAG & & & \\
\hline \multirow[t]{2}{*}{$G / A$} & rs4833095 & F:ACGTTGGATGCTGGAGGATCCTAATGAAAG & chr4:38799710 & exon 4 & {$[52,53,56,62]$} \\
\hline & & R:ACGTTGGATGCCTAAGTATTCTGGCGAAAC & & & \\
\hline \multirow[t]{2}{*}{$\mathrm{T} / \mathrm{C}$} & rs5743595 & F:ACGTTGGATGGGAAATTTCCGGGTCTTTCA & chr4:38802644 & intron & {$[52,53,56,62]$} \\
\hline & & R:ACGTTGGATGGCAAGGAAGATGATGCAGAC & & & \\
\hline \multirow[t]{2}{*}{$\mathrm{C} / \mathrm{T}$} & rs5743596 & F:ACGTTGGATGTGCTCAGGGTCTTCATGAAC & chr4:38802528 & exon 3 & {$[52,53,56,62]$} \\
\hline & & R:ACGTTGGATGGGTGCCCAATATGCCTTTGT & & & \\
\hline TLR 2 & & & & & \\
\hline
\end{tabular}

TLR 2

$\mathrm{C} / \mathrm{T}$

rs1816702

F: ACGTTGGATGGTGTGAGCCTTACTAAAGGT

chr4:154609523 intron

$[52,53,56,62]$ 
R: ACGTTGGATGCTTTGATTCCTCTAGCGCTG

\begin{tabular}{|c|c|c|c|c|c|}
\hline \multirow[t]{2}{*}{$\mathrm{C} / \mathrm{A}$} & rs5743704 & F: ACGTTGGATGTGCATCATAGCAGATGTTCC & chr4:154625951 & exon 3 & {$[52,53,56,62]$} \\
\hline & & R: ACGTTGGATGTGAAAATGATGTGGGCCTG & & & \\
\hline \multirow[t]{2}{*}{$\mathrm{G} / \mathrm{A}$} & rs5743708 & F:ACGTTGGATGCCAGGTAGGTCTTGGTGTTC & chr4:154626317 & exon 3 & {$[52,53,56,62]$} \\
\hline & & R:ACGTTGGATGTTCTTCTGGAGCCCATTGAG & & & \\
\hline $\mathrm{T} / \mathrm{C}$ & rs7656411 & F:ACGTTGGATGCCTTTAAATTACTGTGTATC & chr4:154627655 & $\begin{array}{l}\text { near } \\
\text { gene-3 }\end{array}$ & {$[52,53,56,62]$} \\
\hline
\end{tabular}

R:ACGTTGGATGGTACATGTGAGCTAAATAG

C/T rs11938228 F:ACGTTGGATGTAGGGACATGCCCATATAGG

R:ACGTTGGATGTAGTGTGTTGCTGGTATAGG

G/A rs893629 F:ACGTTGGATGACATCACCTGAAACACACCG

F:ACGTTGGATGACATCACCTGAAACACACCG chr4:154604968

R:ACGTTGGATGGATTCATGAGCCTGAGTTCG

A/G rs1898830 F:ACGTTGGATGGATCCCCTATTTTCTAGCAC

R: ACGTTGGATGAAAACTGGAAAAGGAATAG

C/T rs121917864 F:CACGTGAGTCTGAGTTTC

\section{R:GTCTGGTTCAAGAAGTCATACCCCAACCCA} AGA GAG'

\begin{tabular}{|c|c|c|c|c|c|}
\hline $\mathrm{T} / \mathrm{A}$ & rs4696480 & F : ACGTTGGATGCTCACCATGTGATGCTTTCC & chr4:154607126 & intron & {$[52,53,56,62]$} \\
\hline & & R: ACGTTGGATGGGGAAGTCCAAGATTGAAGG & & & \\
\hline \multirow[t]{2}{*}{$\mathrm{T} / \mathrm{C}$} & rs3804099 & F:ACGTTGGATGCTGCTTCATATGAAGGATCAG & chr4:154624656 & exon 3 & {$[52,53,56,62]$} \\
\hline & & R : ACGTTGGATGGATCTACAGAGCTATGAGCC & & & \\
\hline \multirow[t]{2}{*}{$\mathrm{T} / \mathrm{C}$} & rs5743699 & F :'ATTTGAACTTATCCA GCACACGAAT & chr4:154625291 & exon 3 & {$[52,53,56,62]$} \\
\hline & & R :TCCAGTGTCTTGGGAATGCA & & & \\
\hline \multirow[t]{2}{*}{$\mathrm{T} / \mathrm{C}$} & rs3804100 & F : ACGTTGGATGTTGAACTTATCCAGCACACG & chr4:154625409 & exon 3 & {$[52,53,56,62]$} \\
\hline & & R : ACGTTGGATGTTCCAGTGTCTTGGGAATGC & & & \\
\hline
\end{tabular}

TLR 4

\begin{tabular}{|c|c|c|c|c|c|}
\hline \multirow[t]{2}{*}{$\mathrm{C} / \mathrm{T}$} & rs7869402 & F : ACGTTGGATGTTTAGGGAGACACAGATGGC & Chr9:120478032 & exon 3 & {$[52,53,56,62]$} \\
\hline & & R : ACGTTGGATGACCTTCACACGTAGTTCTCC & & & \\
\hline \multirow[t]{2}{*}{$\mathrm{G} / \mathrm{A}$} & rs1927907 & F: ACGTTGGATGTTTTTCAAACAAGAAGTAG & Chr9:120472764 & intron & {$[52,53,56,62]$} \\
\hline & & R: ACGTTGGATGGGGTATCCAGTGGATTGAAG & & & \\
\hline \multirow[t]{2}{*}{$\mathrm{C} / \mathrm{T}$} & rs1927911 & F: ACGTTGGATGAGACCTTCCTTAGTCATGGC & Chr9:120470054 & intron & {$[52,53,56,62]$} \\
\hline & & R: ACGTTGGATGCATCACTTTGCTCAAGGGTC & & & \\
\hline \multirow[t]{2}{*}{$\mathrm{T} / \mathrm{C}$} & rs1927914 & F : ACGTTGGATGGTGCTTGGAGGATATTACAG & Chr9:120464725 & $\begin{array}{l}\text { near- } \\
\text { gene-5 }\end{array}$ & {$[52,53,56,62]$} \\
\hline & & R: ACGTTGGATGGAACCTGATTTAAAACAGGA & & & \\
\hline
\end{tabular}

$\begin{array}{cl}\text { chr4:154621946 } & \begin{array}{l}\text { near- } \\ \text { gene-5 }\end{array} \quad[52,53,56,62]\end{array}$ neargene-5

$[52,53,56,62]$

chr4:154608453 intron

chr4:154626088 exon $3 \quad[52,53,56,62]$
[52,53, 56,62] 


\begin{tabular}{|c|c|c|c|c|c|}
\hline \multirow[t]{2}{*}{$A / G$} & \multirow[t]{2}{*}{ rs6478317 } & F:ACGTTGGATGTCTATCCCAAGATCGGTTCC & Chr9:120480210 & $\begin{array}{l}\text { near- } \\
\text { gene-5 }\end{array}$ & {$[52,53,56,62]$} \\
\hline & & \multicolumn{4}{|l|}{ R:ACGTTGGATGAAGAGGCTAGAAGAAGATAG } \\
\hline \multirow[t]{2}{*}{$A / G$} & rs55912718 & F: AATTCACCAAGCCCAGGCAGAG & Chr9:120466480 & $\begin{array}{l}\text { near- } \\
\text { gene-5 }\end{array}$ & {$[52,53,56,62]$} \\
\hline & & \multicolumn{4}{|l|}{ R: GAGGAAGTGAAAGCGGCAACCT } \\
\hline \multirow[t]{2}{*}{$\mathrm{G} / \mathrm{A}$} & rs5030719 & F: GCTGAGAAACTTGACCTTCCTGGAC & Chr9:120475936 & $\begin{array}{l}\text { near- } \\
\text { gene-5 }\end{array}$ & {$[52,53,56,62]$} \\
\hline & & \multicolumn{4}{|l|}{ R: AGAACCTGGAGGGAGTTCAGACAC } \\
\hline \multirow[t]{2}{*}{$\mathrm{C} / \mathrm{T}$} & rs10759931 & F: ACCTCAGTGGGCTCTGGGGTAG & Chr9:120464147 & $\begin{array}{l}\text { near- } \\
\text { gene-5 }\end{array}$ & {$[52,53,56,62]$} \\
\hline & & \multicolumn{4}{|l|}{ R: СССTTССТCTGAACСАССТССT: } \\
\hline \multirow[t]{2}{*}{$\mathrm{A} / \mathrm{C}$} & rs10759933 & F :ACGTTGGATGGGTAATAAAATATCCAATATCG & Chr9:120470372 & intron & {$[52,53,56,62]$} \\
\hline & & \multicolumn{4}{|l|}{ R : ACGTTGGATGTGCTCATCTTCTCTGTATCC } \\
\hline \multirow[t]{2}{*}{$\mathrm{T} / \mathrm{C}$} & rs2770150 & F: ACGTTGGATGCACTCAATCATTTACTGACC & Chr9:120463139 & $\begin{array}{l}\text { near- } \\
\text { gene-5 }\end{array}$ & {$[52,53,56,62]$} \\
\hline & & \multicolumn{4}{|l|}{ R: ACGTTGGATGACACATGGTCTGCCTTCTGG } \\
\hline \multirow[t]{2}{*}{$\mathrm{C} / \mathrm{T}$} & rs1554973 & F: TGAAGCCATGAATCATTAAGCCAATA & Chr9:120480812 & intron & {$[52,53,56,62]$} \\
\hline & & \multicolumn{4}{|l|}{ R: TCCAAAAGCCACGCTACTCAAA } \\
\hline \multirow[t]{2}{*}{$\mathrm{C} / \mathrm{A}$} & rs11536878 & F:ACGTTGGATGTTCTTGACTACCCACCACAG & Chr9:120471553 & intron & {$[52,53,56,62]$} \\
\hline & & \multicolumn{4}{|l|}{ R:ACGTTGGATGGCGACATATAACAGTAGGTG } \\
\hline \multirow[t]{2}{*}{$A / C$} & rs11536879 & F: CCTGTTGGGGTCAGAAGACCTG & Chr9:120472211 & intron & {$[52,53,56,62]$} \\
\hline & & \multicolumn{4}{|l|}{ R:CATTTAATCCAGCAGAATAAGTTTCATCATTT } \\
\hline \multirow[t]{2}{*}{$\mathrm{G} / \mathrm{C}$} & rs7873784 & F: ACGTTGGATGGCTCTAAAGATCAGCTGTAT & Chr9:120478936 & exon 4 & {$[52,53,56,62]$} \\
\hline & & \multicolumn{4}{|l|}{ R: ACGTTGGATGGGTACCCTCTTAACAAAATG } \\
\hline \multirow[t]{2}{*}{$\mathrm{G} / \mathrm{C}$} & rs11536889 & F :GTTTCCTGTTGGGCAATG CT & Chr9:120478131 & $\begin{array}{l}\text { near- } \\
\text { gene-3 }\end{array}$ & {$[52,53,56,62]$} \\
\hline & & \multicolumn{4}{|l|}{ R :CATTAATTCCAGCACATTGTTTTCTC } \\
\hline \multirow[t]{2}{*}{$A / G$} & rs4986790 & F: TCTTGCTGGAGTATTCCCTATGA & Chr9:120475302 & exon 4 & {$[52,53,56,62]$} \\
\hline & & \multicolumn{4}{|l|}{ R: GCCACAACCTGCTCTTGC } \\
\hline \multirow[t]{2}{*}{$\mathrm{C} / \mathrm{T}$} & rs4986791 & F:GGTTGCTGTTCTCAAAGTGATTTTGGGAGAA & Chr9:120475602 & exon 4 & {$[52,53,56,62]$} \\
\hline & & \multicolumn{4}{|l|}{ R:ACCTGAAGACTGGAGAGTGAGTTAAATGCT } \\
\hline \multirow[t]{2}{*}{$\mathrm{G} / \mathrm{A}$} & rs11536897 & F: TTCTGCATAAGTGTGTTTATTCAAGCAAA & Chr9:120480010 & exon 4 & {$[52,53,56,62]$} \\
\hline & & \multicolumn{4}{|l|}{ R: TCCAGAGGATTTAAAGAGCTAAAAAGAGG } \\
\hline $\mathrm{C} / \mathrm{A}$ & rs11536898 & F: TTCTGCATAAGTGTGTTTATTCAAGCAAA & Chr9:120480210 & exon 4 & {$[52,53,56,62]$} \\
\hline & & R: TCCAGAGGATTTAAAGAGCTAAAAAGAGG & & & \\
\hline
\end{tabular}

TLR 6

T/C rs3796508 F: ACGTTGGATGgTtgCAAAAGATATCCTGCC $\quad$ chr4: 38830736 exon $1 \quad[52,53,56,62]$ R: ACGTTGgATGgCAgGgCCTTGAAATCATTG 


\begin{tabular}{|c|c|c|c|c|c|}
\hline $\mathrm{C} / \mathrm{T}$ & rs5743810 & F: ACGTTGGATGATTTTTATCAGAACTCACC & chr4: 38830350 & exon 1 & {$[52,53,56,62]$} \\
\hline & & R: ACGTTGGATGAGGCATTTCCAAGTCGTTTC & & & \\
\hline \multirow[t]{2}{*}{$\mathrm{T} / \mathrm{C}$} & rs5743831 & F: GTTGGCTTGAGCACCCAAAATG & chr4:38827414 & intron & {$[52,53,56,62]$} \\
\hline & & R: CTTCTGCCTAACCCCGTGTCCT & & & \\
\hline \multirow[t]{2}{*}{$\mathrm{T} / \mathrm{C}$} & rs1039559 & F: ACGTTGGATGGCAAGCAGCAGACACATCAA & chr4:38831596 & $\begin{array}{l}\text { near- } \\
\text { gene-5 }\end{array}$ & {$[52,53,56,62]$} \\
\hline & & R: ACGTTGGATGCTCAGCCTTTTTTCTCCCAC & & & \\
\hline \multirow[t]{2}{*}{$\mathrm{T} / \mathrm{C}$} & rs6531670 & F: CCACGAGTGCCCACATATTTCAC & chr4: 38835022 & intron & {$[52,53,56,62]$} \\
\hline & & R: CAGTGTCAGTGGCATTTGGGTTC & & & \\
\hline \multirow[t]{2}{*}{$\mathrm{C} / \mathrm{G}$} & rs5743788 & F:ACGTTGGATGGACACTGCAAGAGAGTGAAA & chr4:38833207 & Promoter & {$[52,53,56,62]$} \\
\hline & & R:ACGTTGGATGCAAGTCCCTATCATATATGG & & & \\
\hline \multirow[t]{2}{*}{$\mathrm{C} / \mathrm{T}$} & rs5743794 & F: TGAGTTGCCTTTGCTCGTTTGTC & chr4: 38832727 & intron & {$[52,53,56,62]$} \\
\hline & & R: AGCCAGATAACTGACACCACCTAACA & & & \\
\hline
\end{tabular}

TLR 8

\begin{tabular}{|c|c|c|c|c|c|}
\hline \multirow[t]{2}{*}{$\mathrm{G} / \mathrm{A}$} & rs4830805 & F: ACGTTGGATGAAGGGAACGTGGAAAATCCG & ChrX: 12927759 & intron & {$[52,53,56,62]$} \\
\hline & & R: ACGTTGGATGATCAGCAGAGACCTGATAGC & & & \\
\hline \multirow[t]{2}{*}{$\mathrm{C} / \mathrm{T}$} & rs4830808 & F: ACGTTGGATGGGTAAATGGGTCTCCATTTAG & ChrX:12932334 & intron & {$[52,53,56,62]$} \\
\hline & & R: ACGTTGGATGTCCCACTGGAATTGTTTAGG & & & \\
\hline \multirow[t]{2}{*}{$\mathrm{C} / \mathrm{A}$} & rs3747414 & F: ACGTTGGATGGGTCTTAGTTTCAAGTGCGG & ChrX: 12939412 & exon 2 & {$[52,53,56,62]$} \\
\hline & & R: ACGTTGGATGAGTCAGTAGTCTGAAGCACC & & & \\
\hline \multirow[t]{2}{*}{$A / G$} & rs3761624 & F: ACGTTGGATGTTGGTTTTCTCCСАCTCCTG & ChrX: 12923681 & $\begin{array}{l}\text { near- } \\
\text { gene-5 }\end{array}$ & {$[52,53,56,62]$} \\
\hline & & R: ACGTTGGATGCCCTGGCCACAAGAATAAAG & & & \\
\hline \multirow[t]{2}{*}{$\mathrm{C} / \mathrm{T}$} & rs1548731 & F: ACGTTGGATGACCCAAAGAAGTCCATGAGG & ChrX: 12927947 & intron & {$[52,53,56,62]$} \\
\hline & & R: ACGTTGGATGGAGTGACCTTGAAAACATTC & & & \\
\hline \multirow[t]{2}{*}{$\mathrm{A} / \mathrm{T}$} & rs2109134 & F: ACGTTGGATGCCCAGATGAACTCAGAGATG & ChrX: 12927186 & intron & {$[52,53,56,62]$} \\
\hline & & R: ACGTTGGATGAAGTGCATCATAGTGTCGCC & & & \\
\hline \multirow[t]{2}{*}{$A / G$} & rs3788935 & F: ACGTTGGATGGTCTAGTATCTATGTCAAGC & ChrX: 12922659 & $\begin{array}{l}\text { near- } \\
\text { gene-5 }\end{array}$ & {$[52,53,56,62]$} \\
\hline & & R: ACGTTGGATGGTGTGGAGAAAACTGAAGGC & & & \\
\hline \multirow[t]{2}{*}{$G / A$} & rs1013150 & F: ACGTTGGATGATCACTCAGGGCAGTGTAAG & ChrX: 12932441 & intron & {$[52,53,56,62]$} \\
\hline & & R: ACGTTGGATGTTACTAGGAAAAAGATGAG & & & \\
\hline \multirow[t]{2}{*}{$\mathrm{C} / \mathrm{T}$} & rs5744068 & F: ACGTTGGATGTCATTTCCTTGCTAGCTGCC & ChrX: 12935058 & intron & {$[52,53,56,62]$} \\
\hline & & R: ACGTTGGATGCCCACAACAAGGAATGCAAG & & & \\
\hline \multirow[t]{2}{*}{$\mathrm{G} / \mathrm{C}$} & rs3764879 & F: GTGTGTGTCTGATTTGGGTTG & ChrX:12924697 & intron & {$[52,53,56,62]$} \\
\hline & & R: TTTCTAGGCTCACACCATTTG & & & \\
\hline $\mathrm{C} / \mathrm{T}$ & rs5744080 & F: ACGTTGGATGGCTGACAAATTTGGAGTTGC & ChrX:12937804 & exon 2 & {$[52,53,56,62]$} \\
\hline
\end{tabular}


R: ACGTTGGATGGTAGGGAGCTTGGCAGTTTG

\begin{tabular}{|c|c|c|c|c|c|}
\hline$A / G$ & rs3764880 & F: ACGTTGGATGGCTAAAGAAATAGAAGTGGC & ChrX:12924826 & exon 1 & {$[52,53,56,62]$} \\
\hline & & R: ACGTTGGATGCTGCTGCAAGTTACGGAATG & & & \\
\hline \multirow[t]{2}{*}{$\mathrm{C} / \mathrm{T}$} & rs17256081 & F: ACGTTGGATGGCACTAAAATTTTACAATGC & ChrX: 12926045 & intron & {$[52,53,56,62]$} \\
\hline & & R: ACGTTGGATGATGTGTCATTGGCCCAGTTG & & & \\
\hline \multirow[t]{2}{*}{$\mathrm{C} / \mathrm{T}$} & rs5741883 & F: ACGTTGGATGAAGCGAGCATCTTTCTCCTG & ChrX: 12924221 & $\begin{array}{l}\text { near- } \\
\text { gene-5 }\end{array}$ & {$[52,53,56,62]$} \\
\hline & & R: ACGTTGGATGACAATGAACACTCATTGAGC & & & \\
\hline \multirow[t]{2}{*}{$\mathrm{G} / \mathrm{C}$} & rs2407992 & F: ACGTTGGATGGACTCGCTGGCAAATTAAGG & ChrX: 12939112 & exon 2 & {$[52,53,56,62]$} \\
\hline & & R: ACGTTGGATGGACACGTCTGGATTTATCCC & & & \\
\hline $\mathrm{G} / \mathrm{A}$ & rs178998 & F: ACGTTGGATGCCTAAACTGTATGCATTGCC & ChrX: 12917787 & $\begin{array}{l}\text { near- } \\
\text { gene-5 }\end{array}$ & {$[52,53,56,62]$} \\
\hline
\end{tabular}

TLR 9

A/G rs5743836 F: GaggGtgacAtgGgagCAGAGA $\quad$ Chr3:52260782 Promoter [[52,53,

\begin{tabular}{|c|c|c|c|c|c|}
\hline & & R:CTGTGTAGCCCCTGGGCATTCT & & & \\
\hline \multirow[t]{2}{*}{$\mathrm{G} / \mathrm{A}$} & rs164637 & F:CCCTGCAGGATGACCTCTCTTT & Chr3: 52265215 & exon 2 & {$[52,53,56,62$} \\
\hline & & R:AGGCACCCACCATCTGGATGTA & & & \\
\hline \multirow[t]{2}{*}{$\mathrm{T} / \mathrm{C}$} & rs352139 & F:CTGTGGACATCGATATCGGTGT & Chr3: 52258372 & intron & {$[52,53,56,62$} \\
\hline & & R:AAGCTTCGCTGCGGCAGAAACCCTGT & & & \\
\hline \multirow[t]{2}{*}{$\mathrm{C} / \mathrm{T}$} & rs352140 & F:TCTAGACATCATGCTGGCCATGACC & Chr3: 52256697 & intron & {$[52,53,56,62$} \\
\hline & & R: CAGAGCCACTCAACAGTGGACT & & & \\
\hline \multirow[t]{2}{*}{$\mathrm{T} / \mathrm{C}$} & rs352143 & F: ССCTGCAGGATGACCTCTCTTT & Chr3: 52264907 & exon 2 & {$[52,53,56,62$} \\
\hline & & R: AGGCACCCACCATCTGGATGTA & & & \\
\hline \multirow[t]{2}{*}{$\mathrm{T} / \mathrm{C}$} & rs352162 & F: CCCTGCAGGATGACCTCTCTTT & Chr3: 52252969 & intron & {$[52,53,56,62$} \\
\hline & & R: AGGCACCCACCATCTGGATGTA & & & \\
\hline \multirow[t]{2}{*}{$A / G$} & rs352165 & F: CCCTGCAGGATGACCTCTCTTT & Chr3: 52242902 & intron & {$[52,53,56,62$} \\
\hline & & R: AGGCACCCACCATCTGGATGTA & & & \\
\hline \multirow[t]{2}{*}{$\mathrm{T} / \mathrm{C}$} & rs352167 & F: CCCTGCAGGATGACCTCTCTTT & Chr3: 52238656 & intron & {$[52,53,56,62$} \\
\hline & & R: AGGCACCCACCATCTGGATGTA & & & \\
\hline \multirow[t]{2}{*}{$A / G$} & rs187084 & F:CTGTGGACATCGATATCGGTGT & Chr3: 52261031 & Promoter & {$[52,53,56,62$} \\
\hline & & R:AAGCTTCGCTGCGGCAGAAACCCTGT & & & \\
\hline
\end{tabular}

TLR 10

\begin{tabular}{llllll} 
A/G & rs4129009 & F:CCAGAATGAGTGGTGCCATT & chr4:38773268 & exon 4 & {$[52,53,56,62]$} \\
\hline & & & & \\
\hline A/G & rs7694115 & F: ACGTTGGATGCTATAGGTTGCCTCAAACAG & chr4:38779094 & intron & {$[52,53,56,62]$} \\
\hline
\end{tabular}




\begin{tabular}{|c|c|c|c|c|c|}
\hline & & R:ACGTTGGATGCAGCAGAAGATTTAGAGTCC & & & \\
\hline \multirow[t]{2}{*}{$\mathrm{A} / \mathrm{C}$} & rs10856839 & F: ACGTTGGATGGTTTCTGATGAGTCTCATTG & chr4:38777236 & exon 4 & {$[52,53,56,62]$} \\
\hline & & R: ACGTTGGATGGGGTTTTGAGCTCATCTTC & & & \\
\hline \multirow[t]{2}{*}{$\mathrm{T} / \mathrm{A}$} & rs11466645 & F: GATGAGGAAATTGAAGGATCT3' & chr4:38778203 & exon 4 & {$[52,53,56,62]$} \\
\hline & & R: CACTGCTACTTCCCCAGTGC3' & & & \\
\hline \multirow[t]{2}{*}{$\mathrm{G} / \mathrm{A}$} & rs4274855 & F: ACGTTGGATGTCCTCTCTGAGAATCCTGAC & chr4:38777471 & exon 3 & {$[52,53,56,62]$} \\
\hline & & R: ACGTTGGATGTTGGCTGAGAAGTCTCCAAG & & & \\
\hline \multirow[t]{2}{*}{$\mathrm{A} / \mathrm{C}$} & rs11096955 & F:ACGTTGGATGTGAGAGTTTTCAAGTGAGGC & chr4:38776107 & exon 4 & {$[52,53,56,62]$} \\
\hline & & R:ACGTTGGATGCCAATAATATCTTAACAGACG & & & \\
\hline \multirow[t]{2}{*}{$\mathrm{G} / \mathrm{T}$} & rs11096956 & F:ACGTTGGATGCCTGACAATATCAAATGCAC & chr4:38776180 & exon 4 & {$[52,53,56,62]$} \\
\hline & & R:ACGTTGGATGAATATTGGAATTTCGTAGG & & & \\
\hline \multirow[t]{2}{*}{$\mathrm{A} / \mathrm{C}$} & rs11096957 & F: ACGTTGGATGTAAGCAATAGAACCGATGTC & chr4:38776491 & exon 4 & {$[52,53,56,62]$} \\
\hline & & R: ACGTTGGATGGGCAAAAGCCAATTTGTAAG & & & \\
\hline \multirow[t]{2}{*}{$\mathrm{G} / \mathrm{A}$} & rs7698870 & F: ACGTTGGATGTACCACGGGAATGAACAGAG & chr4:38781459 & intron & {$[52,53,56,62]$} \\
\hline & & R: ACGTTGGATGGATCTCTTCTGAATGACCTC & & & \\
\hline \multirow[t]{2}{*}{$\mathrm{T} / \mathrm{C}$} & rs10776483 & F: ACGTTGGATGATGGAATGGGTTCCAGTAAG & chr4:38775040 & exon 4 & {$[52,53,56,62]$} \\
\hline & & R: ACGTTGGATGTGAATTCTACTTTGCCCACC & & & \\
\hline
\end{tabular}

Table 3: Genotype distributions and Hardy Weinberg Equilibrium in Sudanese tuberculosis patients and healthy controls 


\begin{tabular}{|c|c|c|c|c|}
\hline Genotype & $\begin{array}{l}\text { Tuberculosis patients } \\
\mathrm{N}=160(\%)\end{array}$ & $\begin{array}{l}\text { HWE of patient } \\
\text { population* }\end{array}$ & $\begin{array}{l}\text { Control } \\
\mathrm{N}=220(\%)\end{array}$ & HWE of control population* \\
\hline \multicolumn{5}{|l|}{ TLR 1- rs5743604 } \\
\hline TT & $65(40.62)$ & $<0.01$ & $70(31.82)$ & $<0.01$ \\
\hline $\mathrm{TC}$ & $22(13.75)$ & & $52(23.63)$ & \\
\hline $\mathrm{CC}$ & $73(45.63)$ & & $98(44.55)$ & \\
\hline \multicolumn{5}{|l|}{ TLR 1- rs5743611 } \\
\hline CC & $122(76.25)$ & $<0.01$ & 193(87.72) & $<0.01$ \\
\hline CG & $26(16.25)$ & & 19(8.64) & \\
\hline GG & $12(7.5)$ & & $8(3.64)$ & \\
\hline \multicolumn{5}{|l|}{ TLR 1- rs5743618 } \\
\hline GG & $148(92.5)$ & $<0.01$ & $201(91,36)$ & $<0.01$ \\
\hline GT & $8(5.00)$ & & $17(7.73)$ & \\
\hline TT & $4(2.5)$ & & $2(0.91)$ & \\
\hline \multicolumn{5}{|l|}{ TLR 1- rs76600635 } \\
\hline AA & 152(95.00) & $<0.01$ & $190(86.36)$ & $<0.01$ \\
\hline$A G$ & $7(4.38)$ & & $30(13.64)$ & \\
\hline GG & $1(0.62)$ & & $0(0.00)$ & \\
\hline \multicolumn{5}{|l|}{ TLR 1- rs5743551 } \\
\hline $\mathrm{AA}$ & $130(81.25)$ & $<0.01$ & 197(89.55) & $<0.01$ \\
\hline$A G$ & $15(9.37)$ & & 18(8.18) & \\
\hline GG & 15(9.37) & & $5(2.27)$ & \\
\hline \multicolumn{5}{|l|}{ TLR 1- rs5743557 } \\
\hline $\mathrm{CC}$ & $60(37.5)$ & $<0.01$ & 84(38.18) & $<0.01$ \\
\hline CT & $71(44.38)$ & & $70(31.82)$ & \\
\hline $\mathrm{TT}$ & $29(18.12)$ & & $66(30.00)$ & \\
\hline \multicolumn{5}{|l|}{ TLR 1- rs5743565 } \\
\hline AA & $120(75.00)$ & $<0.01$ & $116(52.73)$ & $<0.01$ \\
\hline$A G$ & $26(16.25)$ & & $65(29.54)$ & \\
\hline GG & $14(8.75)$ & & $39(17.73)$ & \\
\hline \multicolumn{5}{|l|}{ TLR 1- rs5743566 } \\
\hline $\mathrm{CC}$ & 135(84.38) & $<0.01$ & 218(99.09) & $<0.01$ \\
\hline CG & $8(5.00)$ & & $2(0.91)$ & \\
\hline GG & $17(10.62)$ & & $0(0.00)$ & \\
\hline TLR 1- rs5743580 & & & & $<0.01$ \\
\hline $\mathrm{AA}$ & $79(49.38)$ & $<0.01$ & $81(36.82)$ & \\
\hline$A G$ & $39(24.37)$ & Page 20/37 & $44(20.00)$ & \\
\hline
\end{tabular}


TLR 1- rs5743594

CC

70(43.75)

$<0.01$

76(34.55) $\quad<0.01$

CT

22(14.37)

47(21.36)

TT

68(42.5)

97(44.09)

TLR 1- rs4833095

GG

128(80.00)

$<0.01$

198(90.00)

$<0.01$

GA

22(13.75)

18(8.18)

AA

10(6.25)

4(1.82)

TLR 1- rs5743595

\begin{tabular}{|c|c|c|c|}
\hline TT & $122(76.25)$ & $<0.01$ & $212(96,36)$ \\
\hline TC & $10(6.25)$ & & $8(3.64)$ \\
\hline $\mathrm{CC}$ & $28(17.5)$ & & $0(0.00)$ \\
\hline
\end{tabular}

TLR 1- rs5743596

CC

75(46.87)

$<0.01$

72(32.72) $<0.01$

CT

22(13.75)

$50(22.73)$

TT

63(39.38)

98(44.55)

TLR 2- rs 1816702

CC

124(77.5)

$<0.01$

190(86.36)

$<0.01$

CT

24(15.0)

22(10.00)

TT

12(7.5)

8(3.64)

TLR 2- rs5743704

CC

144(90.0)

$<0.01$

212(96,36)

$<0.01$

CA

12(7.5)

$8(3.64)$

AA

$4(2.5)$

$0(0.00)$

TLR 2- rs5743708

GG

154(96.25)

$<0.01$

197(89.55)

$<0.01$

GA

$4(2.5)$

23(10.45)

AA

2(1.25)

$0(0.00)$

TLR 2- rs7656411

TT

128(80.00)

$<0.01$

200(90.91)

$<0.01$

TC

$16(10.00)$

20(9.09)

CC

16(10.00)

0(0.00)

TLR 2- rs11938228

CC

56(35.00)

$<0.01$

75(34.09)

$<0.01$

CT

75(46.88)

78(35.45)

Page 21/37 
TLR 2- rs893629

$\begin{array}{lllll}\text { GG } & 118(73.75) & <0.01 & 104(47.27) & <0.01 \\ \text { GA } & 26(16.25) & & 70(31.82) & \\ \text { AA } & 16(10.00) & & 46(20.91) & \\ \text { TLR 2- rs1898830 } & & & \\ \text { AA } & 150(93.75) & <0.01 & 216(98.18) & <0.01 \\ \text { AG } & 3(1.88) & & 4(1.82) & \\ \text { GG } & 7(4.37) & & 0(0.00) & \\ \text { TLR 2- rs121917864 } & & & \\ \text { CC } & 74(46.25) & <0.01 & 76(34.55) & <0.01 \\ \text { CT } & 46(28.75) & & 47(21.36) & \\ \text { TT } & 40(25.0) & & 97(44.09) & \end{array}$

TLR 2- rs4696480

TT

68(42.50)

$<0.01$

75(34.09) $<0.01$

TA

26(16.25)

47(21.36)

AA

66(41.25)

98(44.55)

TLR 2- rs3804099

TT

TC

124(77.5)

$<0.01$

194(88.18)

$<0.01$

CC

24(15.0)

20(9.09)

12(7.5)

$6(2.73)$

TLR 2- rs5743699

\begin{tabular}{|c|c|c|c|}
\hline TT & $144(90.0)$ & $<0.01$ & $216(98.18)$ \\
\hline $\mathrm{TC}$ & $10(6.25)$ & & $4(1.82)$ \\
\hline $\mathrm{CC}$ & $6(3.75)$ & & $0(0.00)$ \\
\hline
\end{tabular}

TLR 2- rs3804100

TT

66(41.25)

$<0.01$

80(36.36)

$<0.01$

TC

26(16.25)

48(21.82)

CC

68(42.5)

92(41.82)

TLR 4 - rs7869402

CC

128(80.00)

$<0.01$

190(86.36)

$<0.01$

CT

22(13.75)

22(10.00)

TT

10(6.25)

8(3.64)

TLR 4 - rs1927907

GG

144(90.00)

$<0.01$

$210(95,45)$

$<0.01$

GA

12(7.5)

10(4.55) 
$\begin{array}{lll}\mathrm{AA} & 4(2.5) & 0 \\ \mathrm{C} & (0.00)\end{array}$

TLR 4 - rs1927911

\begin{tabular}{|c|c|c|c|}
\hline $\mathrm{CC}$ & $70(43.75)$ & $<0.01$ & $74(33.63)$ \\
\hline $\mathrm{CT}$ & $22(13.75)$ & & $48(21.82)$ \\
\hline TT & $68(42.5)$ & & $98(44.55)$ \\
\hline
\end{tabular}

TLR 4 - rs1927914

\begin{tabular}{|c|c|c|c|}
\hline TT & $126(78.75)$ & $<0.01$ & $188(85.45)$ \\
\hline $\mathrm{TC}$ & $22(13.75)$ & & 20(9.09) \\
\hline $\mathrm{CC}$ & $12(7.5)$ & & $12(5.45)$ \\
\hline
\end{tabular}

TLR 4 - rs6478317

\begin{tabular}{|c|c|c|c|}
\hline $\mathrm{AA}$ & $140(87.5)$ & $<0.01$ & $182(82.73)$ \\
\hline$A G$ & $16(10.0)$ & & $38(17.27)$ \\
\hline GG & $4(2.5)$ & & $0(0.00)$ \\
\hline
\end{tabular}

TLR 4 - rs55912718

\begin{tabular}{|c|c|c|c|}
\hline $\mathrm{AA}$ & $152(95.0)$ & $<0.01$ & $190(86.36)$ \\
\hline$A G$ & $4(2.5)$ & & $30(13.64)$ \\
\hline GG & $4(2.5)$ & & $0(0.00)$ \\
\hline
\end{tabular}

TLR 4 - rs5030719

GG

124(77.5)

$<0.01$

202(91.82) $\quad<0.01$

GA

20 (12.5)

18(8.18)

AA

16(10.0)

$0(0.00)$

TLR 4 - rs10759931

CC

$60(37.5)$

$<0.01$

70(31.82)

$<0.01$

CT

73(45.63)

78(35.45)

27(16.87)

72(32.73)

TLR 4 - rs10759933

$\begin{array}{lllll}\text { AA } & 122(76.25) & <0.01 & 108(49.09) & <0.01 \\ \text { AC } & 24(15.00) & & 68(30.91) & \\ \text { CC } & 14(8.75) & & 44(20.00) & \\ \text { TLR 4 - rs2770150 } & & & & \\ \text { TT } & 150(93.75) & <0.01 & 216(98.18) & <0.01 \\ \text { TC } & 3(1.88) & & 4(1.82) & \\ \text { CC } & 7(4.37) & & 0(0.00) & \end{array}$

TLR 4 - rs1554973

CC

74(46.25)

$<0.01$

76(34.55)

$<0.01$

CT

46(28.75)

48(21.82)

TT

40(25.00)

96(43.63)

Page 23/37 
TLR 4 - rs11536878

$\begin{array}{lllll}\text { CC } & 72(43.13) & <0.01 & 74(33.63) & <0.01 \\ \text { CA } & 40(14.37) & & 48(21.82) & \\ \text { AA } & 48(42.5) & & 98(44.55) & \\ \text { TLR 4 - rs11536879 } & & & \\ \text { AA } & 120(75.00) & <0.01 & 192(87.27) & <0.01 \\ \text { AC } & 28(17.5) & & 22(10.00) & \\ \text { CC } & 12(7.5) & 6(2.73) & \end{array}$

TLR 4 - rs7873784

$\begin{array}{llll}\text { GG } & 144(90.00) & <0.01 & 212(96,36) \\ \text { GC } & 12(7.5) & 8(3.64) & <0.01 \\ \text { CC } & 4(2.5) & 0(0.00) & \end{array}$

TLR 4 - rs11536889

\begin{tabular}{|c|c|c|c|}
\hline GG & $70(43.75)$ & $<0.01$ & $74(33.63)$ \\
\hline $\mathrm{GC}$ & $22(13.75)$ & & $48(21.82)$ \\
\hline $\mathrm{CC}$ & $68(42.5)$ & & $98(44.55)$ \\
\hline
\end{tabular}

TLR 4 - rs4986790

\begin{tabular}{|c|c|c|c|}
\hline$A A$ & $128(80.00)$ & $<0.01$ & $194(88.18)$ \\
\hline AG & $20(12.5)$ & & 18(8.18) \\
\hline GG & $12(7.5)$ & & $8(3.64)$ \\
\hline
\end{tabular}

TLR 4 - rs4986791

\begin{tabular}{|c|c|c|c|}
\hline $\mathrm{CC}$ & $70(43.75)$ & $<0.01$ & $90(40.91)$ \\
\hline $\mathrm{CT}$ & $22(13.75)$ & & $44(20.00)$ \\
\hline TT & $68(42.5)$ & & $86(39.09)$ \\
\hline
\end{tabular}

TLR 4 - rs11536897

$\begin{array}{lllll}\text { GG } & 124(77.5) & <0.01 & 192(87.27) & <0.01 \\ \text { GA } & 20(12.5) & & 24(10.91) & \\ \text { AA } & 16(10.0) & & 4(1.82) & \\ \text { TLR 4-rs11536898 } & & & & \\ \text { CC } & 152(95.00) & <0.01 & 216(98,18) & <0.01 \\ \text { CA } & 6(3.75) & & 4(1.82) & \\ \text { AA } & 2(1.25) & & 0(0.00) & \\ \text { TLR 6- rs3796508 } & & & \\ \text { TT } & 146(91.25) & <0.01 & 202(91.82) & <0.01 \\ \text { TC } & 10(6.25) & & 16(7.27) & \\ \text { CC } & 4(2.5) & & 2(0.91) & \end{array}$


TLR 6- rs 5743810

\begin{tabular}{|c|c|c|c|}
\hline $\mathrm{CC}$ & $130(81.25)$ & $<0.01$ & 203(92.73) \\
\hline CT & 15 (9.37) & & 15(7.27) \\
\hline $\mathrm{TT}$ & $15(9.37)$ & & $2(0.91)$ \\
\hline
\end{tabular}

TLR 6- rs5743831

\begin{tabular}{|c|c|c|c|}
\hline TT & $60(37.5)$ & $<0.01$ & $70(31.82)$ \\
\hline $\mathrm{TC}$ & $73(45.62)$ & & $78(35.45)$ \\
\hline $\mathrm{CC}$ & $27(16.88)$ & & $72(32.73)$ \\
\hline
\end{tabular}

TLR 6- rs1039559

\begin{tabular}{|c|c|c|c|c|}
\hline TT & $70(43.75)$ & $<0.01$ & $100(45.45)$ & $<0.01$ \\
\hline TC & $24(15.00)$ & & $48(21.82)$ & \\
\hline $\mathrm{CC}$ & $66(41.25)$ & & $72(32.73)$ & \\
\hline \multicolumn{5}{|c|}{ TLR 6- rs6531670 } \\
\hline TT & $74(46.25)$ & $<0.01$ & $102(46.36)$ & $<0.01$ \\
\hline TC & $22(13.75)$ & & $40(18.18)$ & \\
\hline $\mathrm{CC}$ & $64(40.00)$ & & 78(35.45) & \\
\hline \multicolumn{5}{|c|}{ TLR 6- rs5743788 } \\
\hline $\mathrm{CC}$ & 128(80.00) & $<0.01$ & $186(84.55)$ & $<0.01$ \\
\hline CG & $20(12.5)$ & & $30(13.63)$ & \\
\hline GG & $12(7.5)$ & & $4(1.82)$ & \\
\hline
\end{tabular}

TLR 6- rs 5743794

\begin{tabular}{|c|c|c|c|c|}
\hline $\mathrm{CC}$ & $122(76.25)$ & $<0.01$ & $216(98,18)$ & $<0.01$ \\
\hline CT & $36(22.50)$ & & $4(1.82)$ & \\
\hline TT & $2(1.25)$ & & $0(0.00)$ & \\
\hline TLR 8- rs4830805 & & $<0.01$ & & $<0.01$ \\
\hline GG & $75(46.88)$ & & $88(40.00)$ & \\
\hline GA & $22(13.75)$ & & 42(19.09) & \\
\hline AA & 63(39.37) & & $90(40.91)$ & \\
\hline TLR 8- rs4830808 & & $<0.01$ & & $<0.01$ \\
\hline $\mathrm{CC}$ & $128(80.00)$ & & 194(88.18) & \\
\hline CT & $22(13.75)$ & & $22(10.00)$ & \\
\hline $\mathrm{TT}$ & $10(6.25)$ & & $4(1.82)$ & \\
\hline TLR 8- rs3747414 & & $<0.01$ & & $<0.01$ \\
\hline GG & $150(93.75)$ & & $216(98,18)$ & \\
\hline GT & $8(5.00)$ & & $4(1.82)$ & \\
\hline TT & $2(1.25)$ & & $0(0.00)$ & \\
\hline
\end{tabular}




\begin{tabular}{|c|c|c|c|c|}
\hline TLR 8- rs3761624 & & $<0.01$ & & $<0.01$ \\
\hline $\mathrm{CC}$ & $146(91.25)$ & & $200(90.91)$ & \\
\hline $\mathrm{CA}$ & $9(5.63)$ & & 20(9.09) & \\
\hline$A A$ & $5(3.12)$ & & $0(0.00)$ & \\
\hline TLR 8- rs1548731 & & $<0.01$ & & $<0.01$ \\
\hline $\mathrm{CC}$ & 131(81.88) & & 204(92.73) & \\
\hline CT & $14(8.75)$ & & $16(7.27)$ & \\
\hline $\mathrm{TT}$ & $15(9.37)$ & & $0(0.00)$ & \\
\hline TLR 8- rs2109134 & & $<0.01$ & & $<0.01$ \\
\hline$A A$ & $58(36.25)$ & & $75(34.09)$ & \\
\hline AT & $73(45.63)$ & & $78(35.45)$ & \\
\hline TT & $29(18.12)$ & & $67(30.45)$ & \\
\hline TLR 8- rs3788935 & & $<0.01$ & & $<0.01$ \\
\hline AA & $69(43.13)$ & & $75(34.09)$ & \\
\hline$A G$ & $23(14.37)$ & & $47(21.36)$ & \\
\hline GG & $68(42.5)$ & & $98(44.55)$ & \\
\hline \multicolumn{5}{|l|}{ TLR 8- rs1013150 } \\
\hline GG & 130(81.25) & $<0.01$ & 204(92.73) & $<0.01$ \\
\hline$A G$ & $14(8.75)$ & & $16(7.27)$ & \\
\hline$A A$ & 16(10.0) & & $0(0.00)$ & \\
\hline \multicolumn{5}{|l|}{ TLR 8- rs5744068 } \\
\hline $\mathrm{CC}$ & $52(32.5)$ & $<0.01$ & $80(36.36)$ & $<0.01$ \\
\hline CT & $76(47.5)$ & & 73(33.18) & \\
\hline $\mathrm{TT}$ & $32(20.0)$ & & $67(30.45)$ & \\
\hline \multicolumn{5}{|l|}{ TLR 8- rs3764879 } \\
\hline GG & $80(50.0)$ & $<0.01$ & $70(31.82)$ & $<0.01$ \\
\hline GC & $40(25.0)$ & & $60(27.27)$ & \\
\hline $\mathrm{CC}$ & $40(25.0)$ & & $90(40.91)$ & \\
\hline TLR 8- rs5744080 & $70(43.75)$ & & 83(37.73) & \\
\hline $\mathrm{CC}$ & $20(12.5)$ & $<0.01$ & $47(21.36)$ & $<0.01$ \\
\hline CT & $70(43.75)$ & & $90(40.91)$ & \\
\hline \multicolumn{5}{|l|}{$\mathrm{TT}$} \\
\hline \multicolumn{5}{|l|}{ TLR 8- rs3764880 } \\
\hline$A A$ & $155(96.87)$ & $<0.01$ & 218(99.09) & $<0.01$ \\
\hline$A G$ & $1(0.63)$ & & $2(0.91)$ & \\
\hline GG & $4(2.5)$ & & $0(0.00)$ & \\
\hline
\end{tabular}




$\begin{array}{llccc}\text { CC } & 86(53.75) & <0.01 & 210(95.45) & <0.01 \\ \text { CT } & 52(32.5) & & 10(4.55) & \\ \text { TT } & 22(13.75) & & 0(0.00) & \\ \text { TLR 8- rs5741883 } & 75(46.88) & & 216(98.2) & \\ \text { CC } & 8(5.00) & <0.01 & 4(1.8) & <0.01 \\ \text { CT } & 77(48.12) & & 0(0.0) & \\ \text { TT } & & & \end{array}$

TLR 8- rs2407992

\begin{tabular}{|c|c|c|c|c|}
\hline GG & $136(85.00)$ & $<0.01$ & $170(77.27)$ & $<0.01$ \\
\hline $\mathrm{GC}$ & $10(6.25)$ & & $40(18.18)$ & \\
\hline $\mathrm{CC}$ & $14(8.75)$ & & $10(4.55)$ & \\
\hline TLR 8- rs178998 & $98(61.25)$ & & & \\
\hline GG & $22(13.75)$ & $<0.01$ & 198(90.00) & $<0.01$ \\
\hline GA & $40(25.00)$ & & $20(9.09)$ & \\
\hline$A A$ & & & $2(0.91)$ & \\
\hline
\end{tabular}

TLR 9- rs5743836

\begin{tabular}{|c|c|c|c|}
\hline AA & $69(43.13)$ & $<0.01$ & $75(34.09)$ \\
\hline$A G$ & $23(14.37)$ & & $47(21.36)$ \\
\hline GG & $68(42.5)$ & & $98(44.55)$ \\
\hline
\end{tabular}

TLR 9- rs 164637

\begin{tabular}{|c|c|c|c|}
\hline GG & $126(78.75)$ & $<0.01$ & $192(87.27)$ \\
\hline $\mathrm{GA}$ & $22(13.75)$ & & $20(9.09)$ \\
\hline AA & $12(7.5)$ & & $8(3.64)$ \\
\hline
\end{tabular}

TLR 9- rs352139

\begin{tabular}{|c|c|c|c|}
\hline TT & $146(91.25)$ & $<0.01$ & $213(96,82)$ \\
\hline $\mathrm{TC}$ & $10(6.25)$ & & $7(3.18)$ \\
\hline $\mathrm{CC}$ & $4(2.5)$ & & $0(0.00)$ \\
\hline
\end{tabular}

TLR 9- rs352140

$\begin{array}{llll}\text { CC } & 155(96.88) & <0.01 & 197(89.55)\end{array}$

TLR 9- rs352143

$\begin{array}{llll}\text { TT } & 129(80.63) & <0.01 & 202(91.82) \\ \text { TC } & 15(9.37) & 18(8.18) & <0.01 \\ \text { CC } & 16(10.0) & 0(0.00) & \end{array}$

TLR 9- rs352162

TT 
TC

CC

TLR 9- rs352165

AG

GG

TLR 9- rs352167

TT

TC

CC

TLR 9- rs187084

\begin{tabular}{|c|c|c|c|}
\hline AA & $76(47.5)$ & $<0.01$ & $74(33.64)$ \\
\hline$A G$ & $44(27.5)$ & & $49(22.27)$ \\
\hline GG & $40(25.0)$ & & $97(44.09)$ \\
\hline
\end{tabular}

78(35.45)

67(30.45)

$106(48.18)<0.01$

70(31.82)

44(20.00)

14(8.75)

152(95.00)

$<0.01$

216(98.18) $<0.01$

$4(1.82)$

$0(0.00)$

7(4.37)
$<0.01$

TLR 10- rs4129009

$<0.01$

TLR 10- rs7694115

AA

GG

TLR 10- rs10856839

AA

AC

TLR 10- rs11466645

TT

TA

AA

TLR 10- rs4274855

GG

GA

AA

TLR 10- rs11096955

AA
75(46.88)

22(13.75)

63(39.37)

$<0.01$

128(80.00)

$<0.01$

22(13.75)

10(6.25)

150(93.75)

$8(5.00)$

2(1.25)

$<0.01$

146(91.25)

$9(5.63)$

5(3.12)

$<0.01$

88(40.00)

42(19.09)

90(40.91)

194(88.18)

22(10.00)

$4(1.82)$

$<0.01$

$216(98,18)$

4(1.82)

$0(0.00)$

$<01<0.01$

200(90.91)

20(9.09)

$0(0.00)$

$<0.01$

131(81.88)

204(92.73)

14 (8.75)

15(9.37)

$<0.01$

58(36.25)
16(7.27)

$0(0.00)$

$<0.01$

$<0.01$

75(34.09) 


\begin{tabular}{|c|c|c|c|c|}
\hline \multirow{2}{*}{$\begin{array}{l}\mathrm{AC} \\
\mathrm{CC}\end{array}$} & \multicolumn{2}{|l|}{$73(45.63)$} & \multicolumn{2}{|l|}{$78(35.45)$} \\
\hline & $29(18.12)$ & & \multicolumn{2}{|l|}{$67(30.45)$} \\
\hline TLR 10- rs11096956 & & $<0.01$ & & $<0.01$ \\
\hline GG & $69(43.13)$ & & 75(34.09) & \\
\hline GT & $23(14.37)$ & & $47(21.36)$ & \\
\hline TT & $68(42.5)$ & & $98(44.55)$ & \\
\hline \multicolumn{5}{|l|}{ TLR 10- rs11096957 } \\
\hline AA & 130(81.25) & $<0.01$ & 204(92.73) & $<0.01$ \\
\hline$A C$ & $14(8.75)$ & & $16(7.27)$ & \\
\hline $\mathrm{CC}$ & 16(10.0) & & $0(0.00)$ & \\
\hline \multicolumn{5}{|l|}{ TLR 10- rs7698870 } \\
\hline GG & $52(32.5)$ & $<0.01$ & $80(36.36)$ & $<0.01$ \\
\hline GA & $76(47.5)$ & & 73(33.18) & \\
\hline AA & $32(20.0)$ & & $67(30.45)$ & \\
\hline \multicolumn{5}{|l|}{ TLR 10- rs10776483 } \\
\hline TT & $80(50.0)$ & $<0.01$ & $70(31.82)$ & $<0.01$ \\
\hline $\mathrm{TC}$ & $40(25.0)$ & & $60(27.27)$ & \\
\hline $\mathrm{CC}$ & $40(25.0)$ & & $90(40.91)$ & \\
\hline
\end{tabular}

Table 4: Allele frequencies of tuberculosis patients in comparison to a matching healthy control population 


\begin{tabular}{|c|c|c|c|c|}
\hline Genotype & $\begin{array}{l}\text { Tuberculosis patients } \\
\mathrm{N}=160(\%)\end{array}$ & $\begin{array}{l}\text { Control } \\
\mathrm{N}=220(\%)\end{array}$ & $\begin{array}{l}\text { P-value for } \\
\text { Association }\end{array}$ & OR $(95 \% \mathrm{Cl})$ \\
\hline \multicolumn{5}{|l|}{ TLR 1- rs5743604 T/C } \\
\hline T-allele & 152 & 192 & 0.352 & $1.03(0.79-1.63)$ \\
\hline C-allele & 168 & 239 & & \\
\hline \multicolumn{5}{|l|}{ TLR 1- rs5743611C/G } \\
\hline C-allele & 270 & 405 & 0.674 & $1.09(0.75-1.45)$ \\
\hline G-allele & 50 & 35 & & \\
\hline \multicolumn{5}{|l|}{ TLR 1- rs5743618G/T } \\
\hline G-allele & 304 & 419 & 0.456 & $1.18(0.75-1.74)$ \\
\hline T-allele & 24 & 21 & & \\
\hline \multicolumn{5}{|l|}{ TLR 1- rs76600635A/G } \\
\hline A-allele & 311 & 410 & 0.182 & $1.20(0.80-1.26)$ \\
\hline G-allele & 9 & 30 & & \\
\hline \multicolumn{5}{|l|}{ TLR 1- rs5743551A/G } \\
\hline A-allele & 275 & 412 & 0.472 & $1.26(0.66-2.24)$ \\
\hline G-allele & 45 & 28 & & \\
\hline \multicolumn{5}{|l|}{ TLR 1- rs5743557C/T } \\
\hline C-allele & 191 & 238 & $<0.0001$ & $1.39(0.77-2.40)$ \\
\hline T-allele & 129 & 202 & & \\
\hline TLR 1- rs5743565A/G & & 297 & 0.672 & \\
\hline A-allele & 266 & 143 & & $1.33(0.67-2.17)$ \\
\hline G-allele & 54 & & & \\
\hline TLR 1- rs5743566C/G & & 438 & 0.344 & \\
\hline C-allele & 278 & 2 & & $1.22(0.85-1.45)$ \\
\hline G-allele & 42 & & & \\
\hline TLR 1- rs5743580A/G & & 206 & 0.455 & \\
\hline A-allele & 197 & 234 & & $1.15(0.76-1.76)$ \\
\hline G-allele & 123 & & & \\
\hline TLR 1- rs5743594C/T & & 199 & 0.621 & \\
\hline C-allele & 162 & 241 & & $1.23(0.78-1.65)$ \\
\hline T-allele & 158 & & & \\
\hline TLR 1- rs4833095 G/A & & 414 & $<0.0001$ & \\
\hline G-allele & 278 & 26 & & $1.17(0.77-1.89)$ \\
\hline A-allele & 42 & & & \\
\hline TLR 1- rs5743595 T/C & & 432 & 0.662 & \\
\hline
\end{tabular}




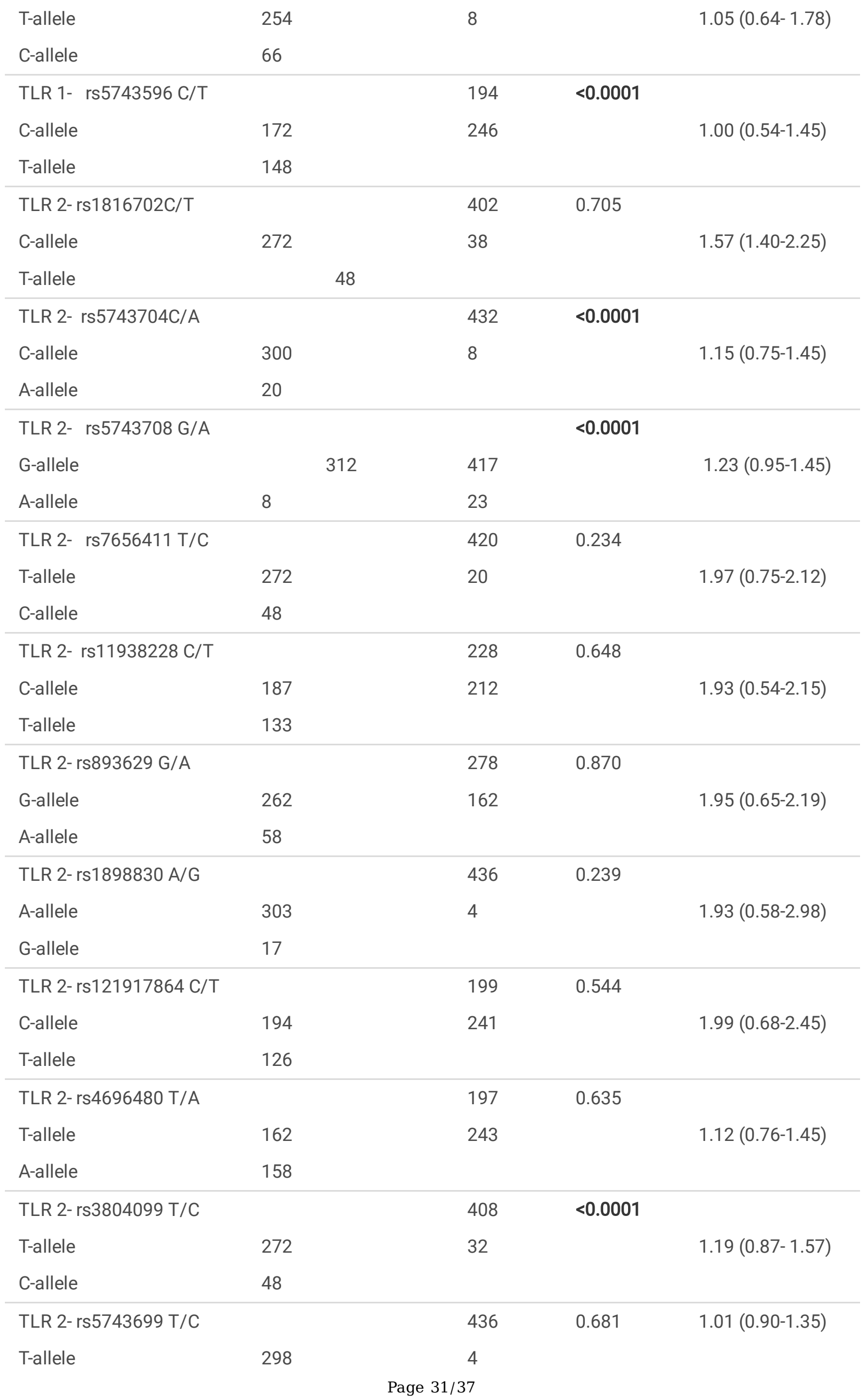




\begin{tabular}{|c|c|c|c|c|}
\hline C-allele & 22 & & & \\
\hline TLR 2-rs3804100 T/C & & 208 & 0.569 & $1.08(0.65-1.19)$ \\
\hline T-allele & 158 & 232 & & \\
\hline C-allele & 162 & & & \\
\hline TLR 4 - rs7869402 C/T & & 402 & 0.528 & \\
\hline C-allele & 278 & 38 & & $1.90(0.60-2.35)$ \\
\hline T-allele & 42 & & & \\
\hline TLR 4 - rs1927907 G/A & & 430 & 0.536 & \\
\hline G-allele & 300 & 10 & & $1.84(0.63-2.12)$ \\
\hline A-allele & 20 & & & \\
\hline TLR 4 - rs1927911 C/T & & 196 & 0.255 & \\
\hline C-allele & 162 & 244 & & $1.02(0.65-1.61)$ \\
\hline T-allele & 158 & & & \\
\hline TLR 4 - rs1927914 T/C & & 396 & 0.225 & \\
\hline T-allele & 274 & 44 & & $1.98(0.77-2.25)$ \\
\hline C-allele & 46 & & & \\
\hline TLR 4 - rs6478317 A/G & & 402 & 0.564 & \\
\hline A-allele & 296 & 38 & & $1.18(1.03-1.33)$ \\
\hline G-allele & 24 & & & \\
\hline TLR 4 - rs55912718 A/G & & 410 & 0.587 & \\
\hline A-allele & 308 & 30 & & $1.06(0.76-1.26)$ \\
\hline G-allele & 12 & & & \\
\hline TLR 4 - rs5030719 G/A & & 422 & 0.434 & \\
\hline G-allele & 268 & 18 & & $1.36(0.72-2.55)$ \\
\hline A-allele & 52 & & & \\
\hline TLR 4 - rs10759931 C/T & & 218 & 0.737 & \\
\hline C-allele & 193 & 222 & & $1.96(0.76-2.23)$ \\
\hline T-allele & 127 & & & \\
\hline TLR 4 - rs10759933 A/C & & 284 & 0.767 & \\
\hline A-allele & 268 & 156 & & $1.90(0.77-2.19)$ \\
\hline C-allele & 52 & & & \\
\hline TLR 4 - rs2770150 T/C & & 436 & 0.307 & \\
\hline T-allele & 303 & 4 & & $1.12(0.94-1.28)$ \\
\hline C-allele & 17 & & & \\
\hline \multicolumn{5}{|l|}{ TLR 4 - rs1554973 C/T } \\
\hline C-allele & 194 & 200 & 0.482 & $1.20(0.99-2.23)$ \\
\hline T-allele & 126 & 240 & & \\
\hline
\end{tabular}




\begin{tabular}{|c|c|c|c|c|c|}
\hline TLR 4 - rs11536878 C/A & & & 196 & 0.881 & \\
\hline C-allele & 184 & & 244 & & $1.58(0.35-2.04)$ \\
\hline A-allele & 136 & & & & \\
\hline TLR 4 - rs11536879 A/C & & & & 0.633 & \\
\hline A-allele & 268 & & 402 & & $1.11(0.95-2.25)$ \\
\hline C-allele & 52 & & 34 & & \\
\hline TLR 4 - rs7873784 G/C & & & 432 & 0.566 & \\
\hline G-allele & 300 & & 8 & & $1.14(0.93-1.32)$ \\
\hline C-allele & 20 & & & & \\
\hline TLR 4 - rs11536889 G/C & & & 196 & 0.235 & \\
\hline G-allele & 162 & & 244 & & $1.12(0.60-2.07)$ \\
\hline C-allele & 158 & & & & \\
\hline TLR 4 - rs4986790 A/G & & & 406 & $<0.0001$ & \\
\hline A-allele & 276 & & 34 & & $1.31(0.65-2.66)$ \\
\hline G-allele & 44 & & & & \\
\hline TLR 4 - rs4986791 C/T & & & & $<0.0001$ & \\
\hline C-allele & & 162 & 224 & & $1.32(0.88-1.187)$ \\
\hline T-allele & 158 & & 216 & & \\
\hline TLR 4 - rs11536897 G/A & & & 408 & 0.663 & \\
\hline G-allele & 268 & & 32 & & $1.40(0.86-2.23)$ \\
\hline A-allele & 52 & & & & \\
\hline TLR 4 - rs11536898 C/A & & & 436 & 0.773 & \\
\hline C-allele & 310 & & 4 & & $1.37(0.83-2.26)$ \\
\hline A-allele & 10 & & & & \\
\hline TLR 6- rs3796508 T/C & & & 420 & 0.235 & $1.54(1.05-2.16)$ \\
\hline T-allele & 302 & & 20 & & \\
\hline C-allele & 18 & & & & \\
\hline TLR 6- rs5743810 C/T & & & 421 & $<0.0001$ & $1.19(0.85-1.76)$ \\
\hline C-allele & 275 & & 19 & & \\
\hline T-allele & 45 & & & & \\
\hline TLR 6- rs5743831 T/C & & & 218 & 0.698 & $1.22(0.73-2.35)$ \\
\hline T-allele & 193 & & 222 & & \\
\hline C-allele & 127 & & & & \\
\hline TLR 6- rs1039559 T/C & & & 248 & 0.623 & $1.11(0.96-1.50)$ \\
\hline T-allele & 164 & & 192 & & \\
\hline C-allele & 156 & & & & \\
\hline
\end{tabular}




\begin{tabular}{|c|c|c|c|c|}
\hline TLR 6- rs6531670 T/C & & 244 & 0.690 & $1.09(0.96-1.45)$ \\
\hline T-allele & 170 & 196 & & \\
\hline C-allele & 150 & & & \\
\hline TLR 6- rs5743788 C/G & & 402 & 0.543 & $1.23(0.53-243)$ \\
\hline C-allele & 276 & 38 & & \\
\hline G-allele & 44 & & & \\
\hline TLR 6- rs5743794 C/T & & 436 & 0.598 & $1.18(0.95-2.45)$ \\
\hline C-allele & 280 & 4 & & \\
\hline T-allele & 40 & & & \\
\hline TLR 8- rs4830805 G/A & & & & $1.92(0.85-4.32)$ \\
\hline G-allele & 172 & 218 & 0.530 & \\
\hline A-allele & 148 & 222 & & \\
\hline TLR 8- $\quad$ rs4830808 C/T & & & & \\
\hline C-allele & 278 & 410 & 0.827 & $1.08(0.56-2.09)$ \\
\hline T-allele & 42 & 30 & & \\
\hline TLR 8- rs3747414 G/T & & & & $1.56(0.93-2.62)$ \\
\hline G-allele & 308 & 436 & 0.517 & \\
\hline T-allele & 12 & 4 & & \\
\hline TLR 8- rs3761624 C/A & & & & $1.90(1.40-2.56)$ \\
\hline C-allele & 301 & 420 & 1.000 & \\
\hline A-allele & 19 & 20 & & \\
\hline TLR 8- rs1548731 C/T & & & & $1.07(0.74-1.55)$ \\
\hline C-allele & 276 & 424 & 0.629 & \\
\hline T-allele & 44 & 16 & & \\
\hline TLR 8- rs2109134 A/T & & & & \\
\hline A-allele & 189 & 228 & 0.299 & $1.68(1.07-2.65)$ \\
\hline T-allele & 131 & 212 & & \\
\hline TLR 8- rs3788935 A/G & & & 0.652 & \\
\hline A-allele & 161 & 197 & & $1.28(0.74,2.22)$ \\
\hline G-allele & 159 & 243 & & \\
\hline TLR 8- rs1013150 G/A & & & & \\
\hline G-allele & 274 & 424 & 0.851 & $1.32(0.74,2.38)$ \\
\hline A-allele & 46 & 16 & & \\
\hline TLR 8- rs5744068 C/T & & & 0.245 & \\
\hline C-allele & 180 & 233 & & $1.98(1.45-2.60)$ \\
\hline T-allele & 140 & 207 & & \\
\hline TLR 8- rs3764879 G/C & & & $<0.0001$ & $1.81(1.31-2.44)$ \\
\hline
\end{tabular}




\begin{tabular}{|c|c|c|c|c|}
\hline G-allele & 200 & 200 & & \\
\hline C-allele & 120 & 240 & & \\
\hline TLR 8- rs5744080 C/T & & & 0.540 & $1.23(0.67,2.27)$ \\
\hline C-allele & 160 & 213 & & \\
\hline T-allele & 160 & 227 & & \\
\hline TLR 8- rs3764880 A/G & & & $<0.0001$ & $1.43(0.79-2.760)$ \\
\hline A-allele & 311 & 438 & & \\
\hline G-allele & 9 & 2 & & \\
\hline TLR 8- rs17256081 C/T & & & 1.000 & $1.10(0.76,1.60)$ \\
\hline C-allele & 224 & 430 & & \\
\hline T-allele & 96 & 10 & & \\
\hline TLR 8- rs5741883 C/T & & & & $1.20(0.92-1.57)$ \\
\hline C-allele & 158 & 436 & 0.618 & \\
\hline T-allele & 162 & 4 & & \\
\hline TLR 8- rs2407992 G/C & & & & $1.26(0.97-1.65)$ \\
\hline G-allele & 282 & 380 & 0.543 & \\
\hline C-allele & 38 & 60 & & \\
\hline \multicolumn{5}{|l|}{ TLR 8- rs178998 G/A } \\
\hline G-allele & 218 & 416 & 0.833 & $1.15(0.77,1.70)$ \\
\hline A-allele & 102 & 24 & & \\
\hline TLR 9- rs5743836 A/G & & & 0.09 & $1.25(0.96-1.66)$ \\
\hline A-allele & 161 & 197 & & \\
\hline G-allele & 159 & 243 & & \\
\hline TLR 9- rs164637 G/A & & & 0.06 & $0.28(0.10-0.90)$ \\
\hline G-allele & 274 & 404 & & \\
\hline A-allele & 46 & 36 & & \\
\hline TLR 9- rs352139 T/C & & & 0.26 & $1.46(0.79-2.75)$ \\
\hline T-allele & 302 & 433 & & \\
\hline C-allele & 18 & 7 & & \\
\hline TLR 9- rs352140 C/T & & & 0.34 & $1.90(1.40-2.56)$ \\
\hline C-allele & 314 & 417 & & \\
\hline T-allele & 6 & 23 & & \\
\hline TLR 9- rs352143 T/C & & & 0.20 & $1.20(0.92-1.57)$ \\
\hline T-allele & 273 & 422 & & \\
\hline C-allele & 47 & 18 & & \\
\hline TLR 9- rs352162 T/C & & & 0.25 & $1.26(0.97-1.65)$ \\
\hline T-allele & 189 & 228 & & \\
\hline
\end{tabular}




\begin{tabular}{|c|c|c|c|c|}
\hline C-allele & 131 & 212 & & \\
\hline TLR 9- rs352165 A/G & & 282 & $<0.0001$ & \\
\hline A-allele & 266 & 158 & & \\
\hline G -allele & 54 & & & $1.91(1.41-2.57)$ \\
\hline TLR 9- rs352167 T/C & 305 & 436 & $<0.0001$ & \\
\hline T-allele & 15 & 4 & & $1.47(0.78-2.76)$ \\
\hline \multicolumn{5}{|l|}{ C-allele } \\
\hline TLR 9- rs187084 A/G & & & $<0.0001$ & \\
\hline A-allele & 196 & 197 & & $1.98(1.45-2.60)$ \\
\hline G-allele & 124 & 243 & & \\
\hline TLR 10- rs4129009 A/G & & & & $1.36(1.01-1.81)$ \\
\hline A-allele & 172 & 218 & $<0.0001$ & \\
\hline G-allele & 148 & 222 & & \\
\hline \multicolumn{5}{|l|}{ TLR 10- rs7694115 A/G } \\
\hline A-allele & 278 & 410 & 0.468 & $1.92(1.19-3.12)$ \\
\hline G-allele & 42 & 30 & & \\
\hline TLR 10- rs10856839 A/C & & & & $1.94(1.14-3.12)$ \\
\hline A-allele & 308 & 436 & 0.729 & \\
\hline C-allele & 12 & 4 & & \\
\hline TLR 10- rs11466645 T/A & & & & $1.13(0.84-1.45)$ \\
\hline T-allele & 301 & 420 & 0.154 & \\
\hline A-allele & 19 & 20 & & \\
\hline TLR 10- rs4274855 G/A & & & & $1.52(0.86-2.58)$ \\
\hline G-allele & 276 & 424 & 0.370 & \\
\hline A-allele & 44 & 16 & & \\
\hline \multicolumn{5}{|l|}{ TLR 10- rs11096955 A/C } \\
\hline A-allele & 189 & 228 & 0.084 & $1.36(0.89-2.06)$ \\
\hline C-allele & 131 & 212 & & \\
\hline TLR10-rs11096956 G/T & & & 0.446 & \\
\hline G-allele & 161 & 197 & & $1.34(0.79-2.28)$ \\
\hline T-allele & 159 & 243 & & \\
\hline \multicolumn{5}{|l|}{ TLR10- rs11096957 A/C } \\
\hline A-allele & 274 & 424 & 0.275 & $1.58(1.01-2.47)$ \\
\hline C-allele & 46 & 16 & & \\
\hline TLR 10- rs7698870 G/A & & & 0.296 & \\
\hline G-allele & 180 & 233 & & $1.35(0.77-2.38)$ \\
\hline
\end{tabular}




$\begin{array}{lcccc}\text { A-allele } & 140 & 207 & & \\ \text { TLR10- rs10776483 T/C } & & & 0.543 & 1.47(0.62-3.56) \\ \text { T-allele } & 200 & 200 & & \\ \text { C-allele } & 120 & 240 & & \end{array}$

P-values are calculated with the Fisher exact test. 